JORGE FERRADA SULLIVAN

Relatos sobre

arte contemporáneo

Estéticas de la presencia en la obra de Alfredo Jaar 

JORGE FERRADA SULLIVAN

\section{Relatos sobre arte contemporáneo. Estéticas de la presencia en la obra de Alfredo Jaar}


Ferrada Sullivan, Jorge

Relatos sobre arte contemporáneo. Estéticas de la presencia en la obra de Alfredo Jaar / Jorge Ferrada Sullivan - Osorno; Editorial Universidad de Los

Lagos, septiembre del 2020

96 p.: I7 X $24 \mathrm{~cm}$ cerrado

RPI: 2020-A-4293 ISBN: 978-956-6043-13-3

I. Arte urbano contemporáneo; 2. Estética del disenso y sensibilidad;

3. Instalaciones artísticas en espacios públicos; 4 . La presencia de lo impresentable en la obra de Jaar

Este libro contó con la aprobación

del Comité Editorial y referato externo

RELATOS SOBRE ARTE CONTEMPORÁNEO.

ESTÉTICAS DE LA PRESENCIA EN LA OBRA DE ALFREDO JAAR

Primera edición: septiembre del 2020

(C) Jorge Ferrada Sullivan, 2020

Registro de propiedad intelectual

$\mathrm{N}^{\mathrm{o}}: 2020-\mathrm{A}-4293$

(c) Editorial Universidad de Los Lagos, 2020

editorial@ulagos.cl

www.editorial.ulagos.cl

Cochrane I070, Osorno

Edición: Carolina Carillanca Carillanca

Dirección de arte: Alexis Hernández Escobar

Portada: Alfredo Jaar. Lights in the City, I999.

Fotografías interiores: Alfredo Jaar. Lights in the City, I 999.

Intervención pública, Bonsecours Market, Montreal.

Courtesy the artist, New York.

Obra financiada con el aporte del

Fondo Nacional del Libro y la Lectura, 2020

Derechos reservados.

Prohibida la reproducción parcial o total de este libro por cualquier medio impreso, electrónico y/o digital, sin la debida autorización escrita del autor y Editorial Ulagos.

Impreso en Santiago de Chile 


\section{JORGE FERRADA SULLIVAN \\ Relatos sobre arte contemporáneo. Estéticas de la presencia en la obra de Alfredo Jaar}
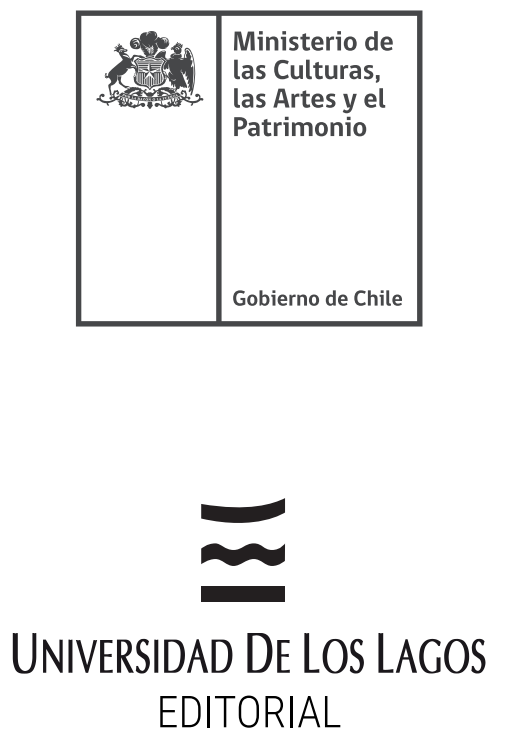

Dedico este libro

a la artista visual chilena Lotty Rosenfeld, por invitarnos a decir en Chile No + 


\section{Contenido}

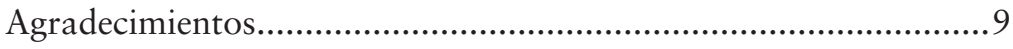

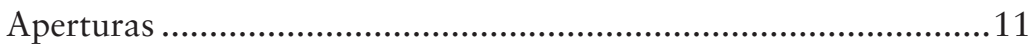

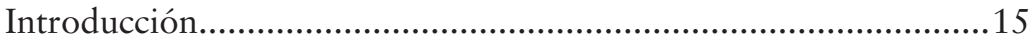

\section{CAPÍTULO I}

EsCribir El CUeRpo DESDE "LightS IN THE City"

I. La invisibilidad de la brillantez de la imagen - cuerpo ..........17

2. Cuerpo al tacto desde Lights in the City.................................23

\section{CAPÍTULO II}

UNA PROPUESTA DE ARTE CONTEMPORÁNEO

I. Hacia una estética de la presencia ...........................................35

2.- La locura del propio cuerpo: lo interno de lo externo ..........45

\section{CAPÍTULO III}

Alfredo JaAr: la enunciación del cuerpo

I. Preámbulo crítico 55

2. La presencia de lo impresentable: una propuesta estética.....57

3. Lights in the City: un testimonio de humanidad ...................61

5. La exposición de los cuerpos en las hospederías ....................75

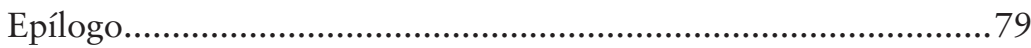

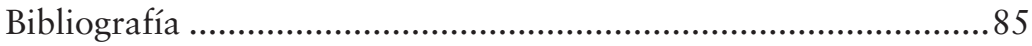

Fuente fotográfica de las imágenes ...............................................8 88

\section{ANEXO}

Escrituras textuales en las obras de Alfredo Jaar .89 


\section{AGRADECIMIENTOS}

El acto de escribir con la intensidad de los cuerpos, pareciera que siempre va acompañada de una sensación de abandono y de incertidumbre. Esta maravillosa palabra, que aprendí hace muchos años del pensador francés Edgar Morin, va a reclamar nuevas lecturas.

Este libro significó algo así como una puesta en común del cuerpo de la palabra, sostenido en la expresión del sentido que expone su permanente imposibilidad de cerrar la significancia del acontecimiento que lo revela. Su estado de reclamación no vendría a ser sino una suerte de distanciamiento a los sentidos originarios que provocó su aparición en el primer lector, en este caso quien reclama desde esta escritura. Agradezco que este texto se mire así mismo desde el borde, desde un horizonte que recordaría al náufrago que anhela el madero, en una estadía aparentemente sin retorno. Quizás su venida, su vuelta a la lectura, hace necesaria esta especie de "toque", sensación justamente de rozar aquello que no cierra la posibilidad de pensarlo como un desciframiento de sus significaciones, sino volver a presentarlo como presencia del cuerpo de la escritura que se revela en mi propia sensación.

Escribir sobre la impronta estética/política de las obras de Alfredo Jaar, me abrió un acceso al pensar filosófico, a la maravillosa experiencia especulativa de situarnos en un mundo de imágenes que nos han dejado sin asombro en su espectacularidad. Jaar como artista me sobre-coge, me expone en y entre la sensibilidad de un mudo mundo indiferente a su propio padecer.

Todas estas líneas tienen sentido para agradecer y testimoniar que junto conmigo, viajaron muchos en mi querida tabla de náufrago: agradezco a la Editorial de la Universidad de Los Lagos, quién confió desde sus inicios en este proyecto literario. Mis tres hijos -Tomás, Antonia y 
Colomba, luces que alumbran cualquier ciudad y su brillantez en mi cuerpo desde sus presencias. A miquerida flamenca por enseñarme a volar y a bailar en las dimensiones ancestrales. A muchos profesores de la Universidad de Chile, que inspiraron mi sentir y mi reflexión desde el límite de este texto. Particularmente le agradezco a Pablo Oyarzún, Juan Manuel Garrido, Adriana Valdés y Rodrigo Zúñiga por la manera en que me invitaron al conocimiento sensible.

Finalmente, dedico este relato a todos los marginales y cuerpos de los hombres invisibles del mundo, que siguen padeciendo la indiferencia de la comunidad en sus propios márgenes. 


\section{APERTURAS}

El libro que a continuación se presenta, pretende reflexionar en torno a la obra de Alfredo Jaar y su controvertido sentido artístico en el supuesto de la utilización de la luz como elemento programático de sus obras. La instalación "Lights in the City", correspondió a un proyecto artístico, realizado por Alfredo Jaar, en el año I999, en la ciudad de Montreal. Esta obra consistió en una intervención pública, que utilizaba un dispositivo de iluminación sobre un edificio monumental (Cúpula del Marché Bonsecours), al interior de uno de los sectores urbanos más recordados de la ciudad -el monumento arquitectónico, fue en su momento, el lugar del parlamento canadiense-. Jaar concibió la brillantez de la cúpula, como un momento pregnante, que recordaba a cientos de hombres desposeídos y sin hogar en una de las ciudades más desarrolladas del mundo capitalista. Este recordatorio que actuaba como huella y testimonio de la indolencia, se vinculaba con la iluminación de la cúpula a través de un dispositivo instalado en algunas hospederías cercanas al edificio señalado. Cada vez que los "homeless" (los sin casa) de Montreal, pulsaban un interruptor desde sus propios sitios de residencia, se iluminaba inmediatamente la cúpula del monumento con un gigantesco flash rojo. La invitación para pulsar dicho interruptor, iba acompañada de un texto declarativo que señalaba los principios de humanidad que justificaban la acción de visibilización de cada uno de esos hombres. Para el artista, una forma de hacer aparecer los cuerpos de la marginalidad y la pobreza desde su propia invisibilidad y silencio.

La mayoría de las creaciones del artista, guardan el secreto de una relación cuerpo-luz-exposición como un valor estético. Sin embargo, 
esta monumental instalación pareciera reunir todos los elementos que motivan este relato, tanto por la visibilización del sentido expositivo de los cuerpos sugerido y simultáneamente borrados en presencia/ausencias, como por la voluminosidad de la obra y su operatoria de tocar a distancia los cuerpos expuestos en la luz (a partir de una estrategia ética-política) para la exhibición del desamparo de los "homeless" en Canadá. En este sentido, al entrar en los cuerpos como un susurro de algo que aparece y que se manifiestan invisiblemente en las obras de Jaar, accedemos al cuerpo de los marginales de Montreal y a la posibilidad de considerar dicha intervención artística, como la presentación de una impronta estética-política en la exposición de la luminosidad de la instalación. En cuestión, dicho gesto nos permite entrar en una nueva problemática, que evidencia nuevas posibilidades de pensar el sentido de la obra "Ligths in the City", como una especulación que transforma el soporte luminosidad de la creación -recordando la marginalidad en Montreal- como el sentido de un aparecer de cuerpos expuestos a nuevas sensibilidades en su representación. Precisamente por el lugar primordial que ocupa el cuerpo, el libro interroga el estatuto de la luz, la brillantez y su exposición -desde la instalación- como una forma exponer dichos cuerpos al sentido de nuevas significaciones.

El gesto estético del artista, tensiona el resplandor visible de la obra para transitar el cuerpo en su exposición y en su distancia al imaginario convencional, basándonos particularmente en el pensamiento del filósofo francés Jean-Luc Nancy y ciertas consideraciones de su pensamiento relativas al cuerpo, al sentido y a la noción de tacto desde una exterioridad. Por este motivo, el interés en esta obra y su posibilidad de exponerla reflexivamente, radica en que en sí misma posee una complejidad de interpretaciones y nuevos sentidos que pueden aparecer en su interpelación. Por un lado, la vieja cúpula en la ciudad de Montreal -desde donde aparece la luz (instalación)- y por otro, la serie de hospederías o casas para los pobres e indigentes de la ciudad, los cuales se vinculan directamente con la instalación mayor. 
Estos dos lugares quedan unidos por el aparecer de esos cuerpos, en la luminosidad de la cúpula del edificio, recordando esos cuerpos marginados. Restos del capitalismo urbano, escondidos y olvidados por la comunidad canadiense, y que también nos recordaría la pobreza encubierta de nuestro país y del mundo.

En consecuencia, el vínculo entre filosofía y creación artística, queda de manifiesto, ya que la obra nos pone en un límite. Nos expone en los bordes del sentido para sentirnos tocados por este tipo de textos visuales. Jaar es un artista del cuerpo en su invisibilidad matérica y por este motivo, Nancy cobra una relevancia fundamental al entender el con-tacto con otros cuerpos como forma de tocar el límite del otro, es decir, lo impenetrable del otro. Esta suerte de transparencia y de opacidad es cautivante y muy transgresora en los propios límites del campo del arte. El observador es interrogado e interpelado una y otra vez, como una verdadera pulsión de visibilidad, como diría Adriana Valdés. La obra nos disloca y nos coloca ahí, nos perturba y nos acoge en todos los desplazamientos que realiza. Por esto la brillantez de la luz siempre será un tacto al que le debemos atención y cautela. 



\title{
INTRODUCCIÓN
}

\author{
El cuerpo presenta rasgos y características \\ peculiares y fundamentales en la delineación \\ de la cuestión de la identidad personal. El \\ cuerpo no es un complemento que se añadiría \\ desde el exterior a una identidad ya designada, \\ connotada e identificada. Sería, al contrario, \\ elemento fundamental, radical y más aún \\ originario de la asignación, atribución y \\ atestación del pronombre "yo".
}

Chiara Lovecchio

El nacimiento del libro Para una estética de la presencia. Relatos sobre arte contemporáneo en la obra "Lights in the City" de Alfredo Jaar, se origina desde el vínculo que existe entre la sensible mirada del lenguaje filosófico y la comprensión de la producción artística y estética del disenso contemporáneo. Dichas relaciones tomarán como referente la obra de Alfredo Jaar y su impronta poética -estética/política- en la utilización de la luz como una verdadera práctica de enunciación ${ }^{1}$.

1 Para el artista Alfredo Jaar, el uso de la luz en las instalaciones es un recurso de mediación entre la signatura de la obra y el espectador. Señala Jaar que "siempre hay un elemento de luz: lo necesito. Es verdad que está enmarcada en un espacio muy oscuro. Siempre me pregunto cuánta luz quiero dejar ver: es un elemento clave del programa. Es una cosa objetiva, un elemento de esperanza. En cada obra está. En algunas no es tan evidente, pero está. Gracias a esta luz puedo seguir haciéndolas". Alfredo Jaar (2006), Conversaciones en Chile, 2005. Barcelona, España. En Catálogo JAAR SCL.: Actar, p. 87. 
Esta suposición se basará en las ideas descritas para el tratamiento de la relación cuerpo/luz, centrando las relaciones filosóficas con esta verdadera seña de la luminosidad para renovar la reflexión sobre el sentido de la creación artística y la escritura sobre el cuerpo. En otras palabras, el uso particular de la luz en la obra de Jaar, indagaría sobre el sentido que transforma el soporte de las creaciones en una presencia de cuerpos que están expuestos a nuevas sensibilidades y para nuevas formas de representación. Este diálogo se sostendría sobre el estatuto del resplandor visible del cuerpo para entender en qué consiste su exposición y la irreductibilidad de dicha exposición al imaginario convencional. En consecuencia, entrar en el sentido con/en Jaar, es entrar también desde una mirada con cierta distancia para el aparecer de nuevos significados posibles y establecidos para cualquier descripción de la obra. 


\section{CAPÍTULO I}

\section{ESCRIBIR EL CUERPO DESDE “LIGHTS IN THE CITY”}

\section{La invisibilidad de la brillantez de la imagen - cuerpo}

Sabido está que el capitalismo tardío, con sus estados fantasmas, su hibridación globalizada, su cultura-consumo bajo la impostura del fetiche, del espectáculo y en el permanente desalojo de la sensibilización de la persona humana, han permitido la generación masificada de imágenes del cuerpo, de figuras corporales, modelos tecno publicitarios de lo corpóreo- que re-presentan formas y referentes de cuerpos inexistentes y simulados. Cuerpos por lo demás, necesarios para el espectáculo y consumo capitalista moderno.

El cuerpo se nos aparece o se nos transparenta en la conciencia de cada cual, en estados de crisis, en momentos de explotación, en heridas, en excesos, en placer. Por esto, el cuerpo que transita desde los inicios de la modernidad en el sistema tecno-capitalista contemporáneo se transforma en un vestigio, en una reducción o en una puntualidad disociada del hombre. La condición normativa racionalista, durante los últimos siglos, ha provocado en el sujeto, una suerte de relativización del valor de su cuerpo como lugar de la afección y de la emoción. El sentir ha quedado como aquel extraño en la incomprensión de su inmanencia y de su exposición. Por esta razón, el sentir el cuerpo como una extrañeza afectiva y en distancia de las significaciones clásicas tendería a transformar la manera en que abordamos la corporalidad del sujeto, como una especie de tacto para nuevas posibilidades de sentido no determinadas por lecturas convencionales. Un tocar o sentirse tocado por aquello que no cierra la posibilidad de pensar el cuerpo como un 
acto descifrado, sino por un acontecimiento por descifrar: el propio sentido que se revela en el espaciamiento de la sensación.

El sentir y las sensaciones que pueden provocar los otros cuerpos, se manifiestan como fuerzas e intensidades corporales, como impulsos y movimientos de sensaciones, capaces de descifrar la exposición del cuerpo más allá (límite) de las tradicionales maneras de presentar su presencia a distancia. Precisamente, el pensar filosófico nos remite a una nueva ubicación o lugar, que bordea el sentido de las significaciones establecidas por las subjetividades dominantes. Se trata aquí de pensar el cuerpo como pensamiento necesario en tanto sentido anterior a toda significación realizada y que permite la posibilidad de apertura de nuevos relatos. He ahí el límite del entendimiento y del sentir. Si transformamos el cuerpo en signos o si pensamos los signos como referencias, no sería posible dejar que el cuerpo se presente en el sentido de su propio límite. Si el sentido depende del pensamiento, en cuanto que es él quien lo acoge, y no quien lo hace, el pensamiento abre su condición de clausura hacia la exposición de nuevos significados o si se quiere, hacia nuevos signos desde la distancia del sentido o "más precisamente el signo de su presencia-a-distancia” (Nancy).

Hacer sentido, sería en consecuencia, tomar distancia de los significados posibles y establecidos para cualquier fenómeno del mundo -entender el límite como una distancia posible-. Dicha posibilidad se enfrenta al pensamiento como confrontación permanente de significaciones históricas y relativizadas culturalmente. La tarea es entonces, tocar la interrupción del sentido para abrir su posibilidad de significaciones allende al límite convencional.

El cuerpo en el capitalismo tardío (fines del siglo XX y XXI), ha masificado sus propias imágenes a modo de arquetipos y dispositivos, que han transformado su propiedad en espectros fetiches y en mercancías preciadas para el consumo social. En el tiempo que nos toca vivir, el cuerpo delata una fractura, una señal incierta, una permanente sensación de opacidad que no es ni poder, ni conquista, sino una puesta 
crisis de la tecno-civilización contemporánea. Por esto, es inquietante interrogar la obra de Jaar desde cuestionamientos como si ¿̇es posible escribir el cuerpo bajo una mirada que logre distanciarse de la variedad de significantes disciplinares?, ¿es posible pensar la marca estético política de la luz en la obra de Jaar como una forma de exponer una corporalidad marginada y silente?

En este contexto, la obra en cuestión, reúne ciertas características generales del programa de proyectos artísticos de Jaar, y por otra parte, ciertas consideraciones específicas de la instalación señalada. Analicemos algunas de ellas:

\section{1}

La mayoría de las obras de Alfredo Jaar, se sostienen en tres principios comunes a la poética de denuncia que el artista realiza a partir de sus instalaciones: En primer lugar, el tratamiento que opera desde la iluminación de ellas -sean éstas imágenes de cuerpos en proyección, palabras que brillan en soportes de neón y propiamente la brillantez minimalista de las obras- que revelan la urgente necesidad de hacer pública la condición de millares de hombres que viven en la marginalidad del sistema capitalista. Esta verdadera cuestión social de la imagen (poética de la luz), reclama permanentemente la necesidad de representación de aquello impresentable para cualquier régimen político: la condición de invisibilidad de aquel resto de humanidad pendiente por su condición de pobreza.

\section{2}

En las instalaciones se aprecia también, una íntima relación entre las palabras, textos, declaraciones, enunciados, y las imágenes propiamente tal (proyecciones de video, fotografías, recursos audiovisuales). La mayoría de ellas, presentan una relación de sustitución y complementariedad entre una y otra. La enunciación textual señala justo aquello que la imagen silencia, y el texto visual aloja en su sentido lo prohibido 
de lo impresentable como una acción programática de opacidades y testimonios silentes en presencias/ausencias.

\section{3}

Las obras pueden presentarse en formatos pequeños y como monumentalidades expuestas y llamativas. Por lo general, el uso de espacios públicos estratégicos, la inevitable atención que el observador debe prestar a las creaciones, el volumen de lo arquitectónico, la grandiosidad de la iluminación, delatan en Jaar la determinación de visibilizar a gran escala y en sitios específicos, a todos los excluidos y oprimidos del mundo, como forma testimonial y ética de ser una voz de denuncia en un mudo mundo ${ }^{2}$.

\section{4}

"Lights in the City" guarda relación con todos los puntos anteriores, en la medida que reúne tres aspectos fundamentales: la visibilización de una opacidad de cuerpos proyectados desde ases lumínicos (cuerpos/ marginalidad), la relación texto e imagen a distancia (el vínculo entre las hospederías y la cúpula del edificio Marchè Bonsecours) y la ubicación de la obra (gran instalación) en un espacio emblemático y público para la ciudad de Montreal. Como señala Zúñiga, el propio Jaar se refirió a esta obra, como el más exitoso de los proyectos artísticos que ha realizado hasta el momento. Se constató lo anterior, en la muestra

2 La monumentalidad en la obra de Jaar, interpela además al espectador en el sentido de tener que observar, algunas veces desde una extrañeza, otras desde de la evidencia perceptible, la interpretación de cuerpos que fluyen y se exponen desde ases lumínicos y textos alusivos que señalan la invisibilidad de la pobreza o del drama de la marginalidad en la ciudad. Quizás y en este contexto, Jaar puede además exponer no solamente el cuerpo del indigente, sino que también la pobreza como un cuerpo, es decir el cuerpo de la pobreza. Pertinente es señalar que además de la obra aludida, el artista ha presentado otras con similares cualidades estéticas y políticas referidas a cuerpos ausentes. Se pueden mencionar: "Señales de Vida - 2000", "Sköghall Konsthall - 2000”, "El Lamento de las Imágenes - 2002”, “El Silencio de las Imágenes - 2006”, entre otras. 
JAAR/SCL/2006, que realizó el artista en el año 2006, Sala Telefónica, donde sus obras, y en particular la referida, fue explicada -en base a un registro fotográfico- como la presentación de la instalación en un contexto urbano que provocaba un acontecimiento inquietante para el observador, ya fuese por la propia sensibilidad del tema y/o por la elección de un lugar público y específico de connotada reputación.

La utilización de la luz como imagen, se basa en una suerte de mandato soberano que Jaar realiza sobre el espectador, en la medida que la percepción y observación de la obra, inevitablemente -quiéranlo o no- es apreciada por una gran cantidad de personas, ya que la instalación se encuentra en un sitio estratégico para los transeúntes que se encuentran cerca de la instalación. Como diría Adriana Valdés, una obra que "fuera sentida por las personas como una interpelación a ellos mismos, como ciudadanos y como habitantes de un espacio común" 3 . En definitiva, el cuerpo de la obra trae ya el cuerpo de los desposeídos, los cuerpos marginados y ocultos del trabajo de instalación de Jaar. La preocupación social y política permanente del artista y su urgencia para hacer aparecer el cuerpo del marginal, desafía su propia obra al transformarse precisamente en una suerte de rescate para una posibilidad de visibilidad: un desvanecimiento de lo visible que pueda reclamar, al mismo tiempo, su necesidad, su permanencia. De cierta manera, es una lógica del testimonio, del trazo testimonial, elemento sustantivo en la obra de este artista: la huella como una referencia, que refiere simultáneamente una impotencia denotativa y una posibilidad de enunciación.

La venida del otro cuerpo o de los cuerpos marginales que Jaar expone en sus obras, hace visible la presencia de una necesidad, de una huella o de un testimonio de hombres sin rostro para una multitud planetaria. Este trazo de ausencias y de corporalidades en olvido, se

3 Oyarzún, Pablo. Richard, Nelly. Zaldivar, Claudia. Editores (2005). Arte y Política. Santiago, Chile: Universidad Arcis, p. 229. 
presentan en la obra del artista, como una especie de índice memorativo, que transita en la instalación descrita, por un medio perceptible pero fugaz, una corporización de evidencias proyectada hacia el infinito desde el movimiento de los cuerpos referidos en la interioridad de la brillantez. Una transparencia que transforma la LUZ en una especie de color - sentido que moviliza una afección y que compromete el cuerpo propio del espectador. Hágase luz, hágase cuerpo, hágase la visibilidad de la transparencia, pareciera ser la exposición significante del artista. Es más, podría suponer que Jaar es un arquitecto del sentido de la invisibilidad de los cuerpos proyectados, desde la brillantez de la iluminación, ya que dichos cuerpos transformados en corpúsculos de luz se presentan como trayectorias de imágenes/cuerpo en la observación interpretativa que realiza el espectador. Al respecto, ¿podría sostenerse que Jaar es un artista del cuerpo y de la luz?

La obra "Lights in the City", puede suponerse como la exposición de una de pulsión de luz, una especie de luminosidad gestual-sensible que interrumpe la cotidianidad del transeúnte por el destello proyectado desde el edificio de la instalación. Desde aquel lugar, se fundaría una posibilidad de advenimiento del cuerpo en la luz, del cuerpo/luz como el tacto del sentido. Este sentido es el que puede tocar el sentir del espectador como una nueva forma de interrogar la obra, que evidencia nuevas posibilidades de pensar el sentido de ésta y como una especulación que transforma el soporte luminosidad de la creación -recordando la marginalidad en Montreal- como el sentido de un aparecer de cuerpos expuestos a nuevas sensibilidades en su representación.

En este contexto, se tensiona el resplandor visible de la obra, para transitar el cuerpo en su exposición y en su distancia al imaginario convencional. Por esto, el valor exhibitivo de la obra, radica en que no se trata de una escena de victimización de los desposeídos, sino por el contrario, la iluminación de los cuerpos proyectados desde la brillantez de la cúpula denuncia públicamente dicha postergación humana a partir del desvanecimiento de la visibilidad de lo que aparece como 
veladura. Esta práctica de enunciación sobre dichos cuerpos, supone que la sensación de "ser tocado" por la exposición de la invisibilidad de los cuerpos marginales (cuerpos/luz), tiene sentido en la medida en que el toque de aquellos cuerpos en el observador, se presentaría como una extrañeza que revela una sensibilidad provocante de la obra y como una distancia posible entre una interpretación del evidente significado de la creación expuesta.

Se podría deducir por extensión, que el gesto político y estético de Jaar, toma en consideración una verdadera poética de la denuncia, por el tratamiento que realiza de la instalación, al sustituir imágenes y palabras que puedan evidenciar la situación de marginalidad, por sensibilidades y sentidos para nuevas interpretaciones. Por esto mismo, la obra de Alfredo Jaar más emblemática en su producción artística, sea "Lights in the City", la cual sitúa al observador en una situación aparentemente ambigua, precisamente por la condición de pensar lo visible desde el límite del sentido de aquella visibilidad: una suerte de objetos sentidos al margen de lo expuesto, de lo realmente visible y significante. Crítica y distancia a la supremacía del sistema, sería una condición relevante de su obra al igual que los textos y catálogos publicados para analizar su trayectoria artística.

\section{Cuerpo al tacto desde Lights in the City}

El relato que a continuación se desarrolla, relaciona directamente dos cuestiones fundamentales en la obra de Alfredo Jaar, las cuales justifican la reflexión filosófica en torno al cuerpo y su posibilidad de presentarlo como una forma de interpelar de manera crítica las condiciones sociales de producción. En este contexto, dicha relación nos pone frente a una problemática al interior del campo del arte referido por una parte, al espectáculo que provoca cierto tratamiento e intencionalidad productiva en las imágenes artísticas en su relación con el espectador, y por otra, la complejidad que subyace en los gestos estéticos que algunos creadores 
instalan en sus obras como trayectos de distanciamiento y fractura en visibilidades aparentemente contradictorias para el observador.

Jaar se encuentra ligado al campo del arte precisamente mediante una operatoria programática del disenso en sus instalaciones. Noción utilizada en muchas oportunidades por el filósofo Jacques Rancière para referirse a un problema no menor en la producción del arte contemporáneo: la desilusión que ha provocado la imagen cada vez que en su relación con el arte, el producto artístico naciente está en complicidad con los medios de circulación y transacción del mercado capitalista. Si pensamos además en la vinculación que la estética posee con el disenso, su punto de encuentro radica en el gesto político que aparece frente al observador. Por tanto, no es que el arte sea político a causa de los mensajes ideológicos que comunica en su definición del estado o de la visión de sociedad que aspira construir. Tampoco por la manera en que representa las estructuras, los conflictos o las identidades sociales en disputa ideológica. Es político en cuanto al distanciamiento que toma respecto de cualquier institucionalidad. Además lo político de las obras se estructura no sólo a través de las creaciones o producciones en sí, sino en lo que comunican dichas obras en un espacio y tiempo específicos. Estas formas de producir obra, son políticas en tanto que sus haceres estructuran formas de visibilidad que reenmarcan el entretejido de prácticas, maneras de ser y modos de sentir y decir en contextos determinados.

Es en este sentido que la obra "Lights in the City" instala la urgencia de transformar aquellos cuerpos marginales, en luces, destellos y brillanteces para representar todas las presencias de la pobreza que incomodan la ciudad o cualquier urbe moderna. No está demás señalar que para los países capitalistas con alto grado de desarrollo (en Norteamérica y Europa entre otros), la mirada crítica hacia los países del tercer mundo radica precisamente en la imposibilidad que estos han tenido para superar la pobreza y la vulnerable presencia de políticas de equidad para la estabilidad social y cultural. Este hecho se manifiesta 
concretamente como un permanente recordatorio de la condición de subdesarrollo que estos países representan. Por este recordatorio permanente la obra aludida, permite iluminar lo no visible de la pobreza como una manera de inscribir en torno a dicha luminosidad la ausencia del otro, de lo otro y en consecuencia, no la ausencia del cuerpo como objeto de la representación, sino la ausencia de todo cuerpo que evidencie la marginalidad, la postergación económica y la exclusión social.

La producción de Alfredo Jaar, se inscribe en la complejidad del arte contemporáneo en virtud de la considerable multiplicidad de propuestas que se agrupan bajo esta noción, ya sean vanguardistas tendencias representacionales o anti-informalismos que desbordan la manera usual de entender el arte y su representación (podrían nombrarse como ejemplo de estas tendencias: las performances de Lygia Clark, las manifestaciones de los activistas vieneses, las intervenciones callejeras de Oleg Kulik, el transformismo corporal de Orlan, las escenográficas fotografías de Jan Saudek, las instalaciones corporales de Marc Quinn, entre muchos otros). Los fundamentos político-estéticos de Jaar logran entrar en la existencia cotidiana para reordenar los códigos y gestos que constituyen y configuran las relaciones sociales modernas. Para el campo artístico contemporáneo, la forma explícita de la obra o las creaciones producidas por artistas como Jaar, no existen si no es a través del otro, porque es el otro quien posibilita su existencia y construcción para el observador.

Al igual que otros artistas contemporáneos que desmarcan con sus obras al cuerpo -como estrategias biopolíticas en espacios de interacción ${ }^{4}$-, la estética poética y política de Jaar propone como eje el

4 Para profundizar la relación entre la producción artística contemporánea y la noción de biopolítica, remito al lector a un texto escrito por el filósofo chileno Rodrigo Zúñiga (2008). “La Demarcación de los Cuerpos”, Metales Pesados. Señala Zúñiga: "El libro es una propuesta para pensar la articulación biopolítica que opera en algunas manifestaciones artísticas, particularmente en aquellas que asumen estrategias de participación, de intervención material o de demarcación soberana sobre los cuerpos". 
diálogo, la intersubjetividad y el carácter indiscutiblemente relacional y participativo con el espectador. Podría sostenerse que corresponde a una producción de arte que se fundamenta a sí misma como comunitaria para una comunidad prácticamente cegada por la vorágine tecnológica y sus imágenes fetiches.

Con este tipo de formas estéticas y representacionales, las creaciones artísticas han evidenciado explícitamente lo impresentable o irrepresentable de ciertos temas sociales pendientes como la otra cara del capitalismo o de todo sistema que atente contra la dignidad humana. Para pensar en un arte de lo impresentable hay que hacer venir aquello impresentable desde otra parte que desde el arte mismo. Hay que hacer coincidir lo implícito prohibido como representación y lo imposible de presentar como obra de arte, ya sea por la contradicción que provoca en el sistema imperante como por la perturbación que suscita en lo políticamente correcto.

Una comunidad del sentir, en términos de Rancière, es sin duda alguna aquella que hace posible considerar al arte una parte fundamental de la estructura social. Para este filósofo los factores que intervienen en las determinadas prácticas creativas del disenso se encuentran vinculados con formas de visibilidad y modos de inteligibilidad específicos para cada contexto de instalación, en los cuales, como ya mencionamos, confluyen la historicidad del fenómeno en cuestión, el campo artístico e incluso la idea de que en ese momento la moda sobrepasa al artista en tanto productor de obras para experiencias estéticas distintas. El problema no es saber si se puede o se debe o no representar, sino qué se quiere representar y qué modo de representación se elige para provocar una reflexión en la propia interrupción cotidiana.

Las creaciones de Jaar están expuestas a partir de mensajes, frases, signos y huellas, que son escritas en todas y con todas sus partes, desde la interioridad sensible de los cuerpos en obra hasta las maneras en que el artista comunica en los receptores aquel mensaje intencionado. Espacio de sentido técnico y proyecto concreto que no permite una tradición 
conceptual, ni menos un "algo" esperado en sus proyectos artísticos. Sin embargo, el con-torno del cuerpo en la producción de la obra elegida, escribe el en-torno del tacto en todos los cuerpos fuera del cuerpo. Los cuerpos en las instalaciones, se palpan y se encuentran, se tornan y se trastornan. ¿Es posible pasar por alto el mundo de los cuerpos o de la obra como cuerpo sin retirarse de lo visible? En esta operación, se provoca una materialidad productiva, una suerte de conmemoración susurrante de la propia existencia ya que la obra como acontecimiento, inscribe el cuerpo que se nombra desde la corporización de los pobres del presente. El observador lo recibe y se enmudece.

Con esta aparición de cuerpos (en obra), no es posible un discurso que conceptualice y defina lo posible de encontrarse entre los cuerpos, quizás como el genuino sentido de ser y estar en presencia en el mundo junto con otros. Para Nancy, "la significación se vacía precisamente porque cierra su proceso subjetivo: no tiene por sentido más que a si misma, en su inercia, es decir, a la vez su propio deseo, su propia proyección, su propia distancia de representación (...)" " Por esto, en la obra de Jaar, la representación a distancia -no solamente en "Lights in the City", sino también en muchas de sus obras.

La experiencia de los cuerpos proyectados en la luz y expuestos hacia la espacialidad de trayectorias insospechadas, permiten revelar ante el mundo de los espectadores, un tacto de la exposición de los cuerpos, a través de sus sentidos dispuestos a internalizar la poética de la obra. Cada elemento creativo y expuesto de las obras de Jaar, está destinado a depositar un mensaje en cada cuerpo presente, para despertarles una sensibilidad interna que los hará vivenciar la experiencia sensible de ser tocados desde un lugar de los cuerpos. La acción de tocar y ser tocado al límite se caracteriza por ser una entrega de un cuerpo que expone su ser íntimo a los demás cuerpos, es un gesto de apertura y exposición

5 Nancy, Jean Luc (2003). El Olvido de la Filosofía. Madrid, España: Arena Libros, p. 48 . 
del ser sensible donde a través de la obra, el artista comunica desde un lenguaje sintiente. El efecto que esta acción logra, es la provocación del sensible interno de los observadores, para que logren sentir y conmoverse con lo que expresa el creador, que expone también su ser sensible para compartir su experiencia emotiva a través del toque de la obra. Ofrece su cuerpo para que sea percibido y acogido por un mundo de cuerpos sensibles. En Corpus Nancy sostiene al respecto:

El modo en que los cuerpos se ofrecen entre sí, son la puesta en el mundo, la puesta en el borde, la glorificación del límite y del resplandor. Un cuerpo es una imagen ofrecida a otros cuerpos, todo un corpus de imágenes que pasan de un cuerpo a otro, colores, sombras locales, fragmentos, granos, areolas, lúnulas, uñas, pelos, tendones, cráneos, costillas, pelvis, vientres, meatos, espumas, lágrimas, dientes, babas, fisuras, bloques, lenguas, sudores, licores, venas, penas y alegrías, y yo, y tú6.

Esta exposición es una presentación que evidencia la sensibilidad del artista cómo un cuerpo capaz de conmoverse, emocionarse y estremecerse con lo que percibe de sí mismo y del mundo. La acción de entrega del toque de un sensible a otro resuena en todo el ser comprometiendo carne, músculos, órganos y huesos del cuerpo, además de la mente, recuerdos, pensamientos, ideas e imaginarios para disponerse a ser estremecido con lo que los toca desde su espaciamiento. Este resonar causado por un toque nos hace recuperar nuestro ser sensible y por qué no decirlo, a veces oculto y desatendido dentro de tanta materialidad y consumo actual. Con Jaar, la sensibilidad que nos toca desde la exposición de la obra "Lights in the City", precisamente toca lo visible de la invisibilidad del aparecer de los cuerpos marginados, ya que en su entendimiento, el pensamiento queda suspendido sobre el

6 Nancy, Jean-Luc. Corpus (2003). Madrid, España: Arena Libros, p. 92. 
afuera del sentido mismo que nos toca desde la cúpula. En esta operación, se provoca una materialidad productiva ya que la obra como acontecimiento, inscribe el cuerpo que se nombra en la corporización de los pobres del presente. Nos hace escapar del mundo mecánico para entrar en un mundo de imaginación, de afectos y emociones que nos permiten encontrarnos con la esencia pura, esa que nos conecta con el universo, con la naturaleza y con los demás cuerpos. Esta es la belleza del efecto de tocar y de tocarse, para encontrarnos con nuestra esencia sensible y perceptiva.

La constitución del cuerpo que se vincula estrechamente con el mundo representado y expuesto en la obra "Lights in the City", es un pre-texto para pensar el cuerpo y todos aquellos que son arrojados por la luminosidad de la cúpula al firmamento. Una forma en que la poética de la creación instalada, re-escribe una escritura indescifrable para el entendimiento. Quizás la seña que provoca la luminosidad como manera de escribir en su exposición, cuerpos de la invisibilidad e imperceptibles por la razón. El cuerpo es pensado también como condición de su lejanía a lo pensable. Claro está, que el cuerpo presentado en dichas condiciones se manifiesta quizás de mayor manera, en las construcciones de obra que realiza el artista. En Jaar el cuerpo está presente en su invisibilidad. En ese presente están convocados todos los cuerpos sin tiempo, en ese tiempo es necesario ser tocado por la gravitación y suspensión de todos los cuerpos. Nuestro asombro: el que podamos tocar lo intocable del cuerpo en la materialidad observada de la obra: sentir nuevos pensamientos en la desnudez de la creación.

En aquel lugar de Montreal el aparecer de la obra, no se representa manifiestamente en la literalidad de lo expuesto. Es cierto que el espectador visibiliza elementos de la obra que, objetivamente, se exponen de manera reconocibles y evidentes a la vista del observador. También es cierto que en la conjunción de dichos elementos existe un resto por descifrar que no quedan declarados en su evidencia. Las interpretaciones que el observador puede realizar en torno a la ubicación de la obra en 
ese edificio y su relación con la iluminación de la cúpula, se comportan como enunciaciones de un trayecto por desentrañar. Por esto mismo, la propuesta de Jaar no radica en lo manifiesto de dichos dispositivos expuestos en tanto materialidades objetivas y condiciones técnicas del proyecto artístico para su realización e instalación -estructuras físicas, dispositivos electro lumínicos, signos lingüísticos, etc. Es condición de la relación de estos factores y de la intencionalidad creativa y estética-política del artista -que en los límites de la visibilidad objetiva- es posible dejar abierta la posibilidad de exponer la evidencia para nuevas interpretaciones. Toda realidad física en la obra, está dada a partir de aquellas propiedades técnicas. Aunque todo aquello es real, en la obra del artista, estas cualidades objetivas y observadas se fusionan y se funden desde el sentido de la proyección lumínica. Su trayectoria transita por el sentido del mundo que dichas cualidades escriben como un sentir. Mundo por lo demás que despliega la obra en la manifestación de aquel sentido que el propio arte puede ofrecer. Como señala Nancy,

el sentir y el sentirse - sentir que constituye el sentir mismo es siempre sentir a la vez que existe lo otro (lo que uno siente) y que hay otras zonas del sentir, ignoradas por la que siente en este momento, o bien tocadas por doquier por esta, pero sólo a través del límite en que ella deja de ser la zona que es

Quizás sea por esto, que el arte no tenga que ver con el mundo, entendido como exterioridad visible, más bien tiene que ver con el ser-enel-mundo, su llamamiento y venida que le es singular en un mundo de cuerpos, en una comunidad de cuerpos que se tocan.

Algunos comentarios finales que evidencian las anteriores argumentaciones. Hace pocos años, Alfredo Jaar fue galardonado con el Premio Nacional de Artes-20I3 y expositor en la versión $55^{\text {a }}$ de la Exposi-

7 Nancy, Jean-Luc (2008). Las Musas. Buenos Aires, Argentina: Amorrortu, p. 3 I. 
ción Internacional de Arte - Bienal de Venecia con la obra "Venezia, Venezia”. En esta muestra el artista realizó una instalación - maqueta del parque Giardini- simulando el espacio que alberga los pabellones permanentes de la Bienal. Dicha maqueta emergía y se sumergía cada tres minutos en un estanque lleno de agua. Situación que provocó en el espectador cierta inquietud y extrañeza ante lo observado.

En el sitio web Plataforma Arquitectura, se puede visualizar una entrevista realizada a Jaar que explica las razones que lo llevaron a crear la obra expuesta y a la crítica que éste realiza al espacio de exhibición italiano. Dos citas de aquella que complementan reflexiones precedentes para la obra de este artista: "frente al cuestionamiento a la estructura de los pabellones, de acuerdo a Jaar, obsoleta y poco democrática, el artista exhibió una maqueta en escala I:60 del Giardini (...)"; “24.860 oportunidades de imaginar un orden diferente, de una especie de democracia cultural abierta a todos" ${ }^{8}$. Cantidad de veces en las cuales puede pensarse creativamente una Bienal distinta y abierta a todos los artistas del mundo y no solamente a los países que tradicional e históricamente han expuesto al mundo sus artistas y propuestas. Contrapone nuevamente nociones como la de participación versus exclusión, en este caso de los artistas (marginales) y sus producciones.

¿En qué sentido(s) se presenta en el espectador, el gesto estético/ político de las obras Jaar?:

i. La relación que establece en sus creaciones entre la producción de obra y sus implicancias con la vida social de las comunidades urbanas. Una convocatoria a pensar el arte y la vida como una fusión indispensable. El compromiso al cual invita con dicha relación conlleva a recordar y a justificar la responsabilidad y el vínculo que

8 Ver video completo en sitio web www.plataformaarquitectura.cl/20I3/o9/ro/alfredo-jaar-premio-nacional-de-arte-20I3/ (Revisado en diciembre del 2013). 
muchos artistas e intelectuales poseen con el pensamiento crítico - estético contemporáneo.

ii. La puesta en escena de las obras, seducen también estos argumentos a partir del tratamiento crítico que realiza en torno a las imágenes y a la forma en que ellas logran conmover y afectar al espectador. Esta afección se traduce en aquel resto de extrañeza o inquietud por la interpelación que provocan las obras. Sin duda, obras que tocan el sentir y el pensamiento del observante.

iii. Se le ha criticado que el uso y el tratamiento que realiza de las imágenes de la marginalidad, del dolor o de la exclusión, podrían ser las banderas visuales de organizaciones pro derechos del hombre. Sin embargo ya se encuentra en muchos casos arraigada la espectacularidad en la circulación institucional de dichas imágenes, lo que transforma banalmente la visualidad de la pobreza o la exclusión como medios de marketing para la superación de aquellos conflictos. Lo visual en el gesto político-estético de Jaar es decisivo para que el observador logre sentirse partícipe del mundo y para el mundo, del otro y con los otros.

iv. Entre ver y comprometerse, entre silenciarse e involucrarse existe una abismante distancia que nos separa a muchos de la sociedad del espectáculo actual. En este sentido, el tipo de obra que expone este artista, se encuentra inserta en el mundo para tener presente y recordarnos en la memoria que somos parte de la realidad y no ajenos a ella. Podemos escribir y reescribir críticamente la situación actual del mundo, sin embargo el poder de las imágenes y sobre todo cuando éstas creativamente producen el tipo de obra al estilo de Jaar, provocan que la visualidad se exponga en el límite de la conmoción, de la emoción, del pensamiento y de la acción. No será entonces una casualidad que muchos observadores de sus obras y participantes de sus conferencias se sientan tocados en el sentir de lo expuesto. Culmino con una cita complementaria a estos puntos que identifican plenamente estas líneas: 
Refiriéndose Jaar al Proyecto Ruanda que culminó con la obra El Silencio de Nduwayesu:

Políticamente mi primera función es decir “existe este país, hubo un genocidio y no hicimos nada, murieron un millón de personas, esto es lo que podríamos haber hecho". Me podrías decir, esto no es arte. Pero hay maneras y maneras de hacerlo. Si me quedo sólo en información pública, bruta, no es interesante como arte. Quiero lograr conmoverte, desafiarte, tocarte. Quiero lograr enojarte, provocarte: eso es una labor política9.

9 Alfredo Jaar (2006), Conversaciones en Chile, 2005. Barcelona, España. En Catálogo JAAR SCL: Actar., p. 83. 



\section{CAPÍTULO II}

\section{UNA PROPUESTA DE ARTE CONTEMPORÁNEO}

\section{Hacia una estética de la presencia}

En la actualidad las creaciones de Alfredo Jaar se han transformado en sugerentes críticas sociales a partir de la forma-contenido-mensaje con la cual trabaja las imágenes. Sus intervenciones en la sociedad tardo-capitalista y en el mundo globalizado, se han realizado en espacios públicos y en sitios emblemáticos para transeúntes y observadores. Esta condición reciente de la visualización de sus proyectos creativos, ha sido la impronta como artista y creador. Cabe mencionar al respecto, una de las más importantes intervenciones públicas realizadas en tiempos de la dictadura militar: me refiero a la obra Estudios sobre la Felicidad: I980-I98 $\mathrm{I}^{10}$. Corresponde a una serie de intervenciones experimentales realizadas en la ciudad de Santiago con diversos soportes de producción: entrevistas, videos, perfomance, intervenciones urbanas y registros fotográficos.

10 La obra completa corresponde a una serie de ocho fotografías en blanco y negro, cinco apaisadas y tres verticales, que registran intervenciones realizadas en la ciudad de Santiago y sus alrededores, incorporando la pregunta “¿Es Usted Feliz?” al paisaje, en vallas publicitarias de pequeño y gran formato, con tipografía negra sobre fondo blanco. Las imágenes exhiben en su impresión, un marco correspondiente a una película fotográfica, la cual nos indica su condición de registro, evidenciando el medio utilizado para documentar la ejecución de la obra y su carácter efímero. La serie donada por el artista a la colección del museo, obedece a una edición especial impresa por él durante el presente año. En http://www.mac.uchile.cl/educacion/colección_arte_experimental/ alfredo_jaar.pdf (Revisado en Noviembre del 20I3) 
La idea era abstraer al público de la cotidianidad dictatorial, formulando la pregunta: ¿Es Usted Feliz? Hago referencia a esta propuesta de Jaar, a propósito de ciertos elementos que tienden a repetirse en las obras posteriores y recientes del artista. En la intervención de I98 I, su alusión indirecta al cuerpo está presente desde la interpelación lingüística realizada a los ciudadanos comunes y corrientes. La expresión de felicidad o su ausencia, se explicita en la corporalidad del sujeto. Las afecciones delatan una cierta corporización de la emoción que pone en movimiento el cuerpo del individuo. Sospecho que por esa razón Jaar pone en circulación esa pregunta y no otra, ya que bajo el gobierno militar gran parte de la población chilena se encontraba sumida en una inmanente melancolía producto de las marcas imborrables que se sucedieron luego del golpe militar. En "Lights in the City" existe otro tipo de golpe que recuerda la pobreza invisible de Montreal y del mundo. En ambas la intervención debía ser pública para hacer partícipe al espectador de una situación problemática que recordaba un hecho traumático o en creciente olvido.

El cuerpo para la escena del arte en el artista Alfredo Jaar, es precisamente la relación entre lo expuesto en un espacio y un tiempo, y lo que se logran espaciar fuera del tiempo y de aquel espacio. Si bien es cierto que las obras están objetivamente situadas en contextos temporo-espaciales determinados, estas dimensiones amplían su horizonte cuando involucran hechos universalmente importantes para la humanidad (pobreza, marginación, acciones de poder explícitos o implícitos, desolación, indiferencia, etc) que pueden estar afectando a otros lugares distintos y distantes. Por eso mismo, todas las situaciones que social o políticamente interpelan al sujeto por sus evidencias o por sus extravíos, desastres o flagelos mundiales, se vinculan con todos los hombres que padecen similar situación más allá del lugar de realización -una suerte de conmemoración testimonial y de identificación psico-social. Por cierto, sospecho que en lo programático de Jaar, la pregunta de I98 I ¿Es Usted Feliz? está dirigida a los transeúntes y público en 
general con algunas pretensiones ocultas. Si bien los encuestados no estuvieron bajo ninguna determinación ni orden establecido para llevar a cabo esta acción ¿para qué Jaar realiza esta pregunta? ¿qué subyace en su interior?

En toda esa performance no le interesaba exclusivamente las respuestas de los encuestados en ese momento, sino que pareciera interpretativamente que su interés radica en la palabra ser feliz o no serlo en el contexto histórico que se estaba viviendo. ¿En qué sentido o en qué condiciones de la época se podría o no ser feliz? ¿será que los entrevistados en esa ocasión serían una pequeña muestra de gran parte de un pueblo infeliz que Jaar suponía? Suposición en todo caso que puede ser analizada a partir de la interpretación que puede desprenderse de la situación histórica. Lo mismo podría suponerse con lo que recurrentemente aparece en su obra en las últimas décadas. Una suerte de ideario creativo que posee el artista como impronta estético-política ya sea por lo que podemos interpretar localmente (I98I) como lo que desplegará en la mayoría de sus obras a partir del año 2000. Si bien es cierto que cada obra está situada en un contexto particular, el mensaje que se proyecta desde aquello local cobra ribetes universales por las temáticas que expone (sufrimiento, incertidumbre, marginalidad, indiferencia, elitismo, etc). Interpreto entonces lo que ocurre con aquello que recuerda la luminaria encendida en la obra "Lights in the City": ¿serán solamente los pobres de Montreal o se difundirá la luz a todos los marginales del mundo?

Lo expuesto en la visión, es el movimiento de la corporalización del sentido de un mundo encarnado y realizado en el cuerpo. El cuerpo es la obra de Jaar, en la medida que nos conduce al encuentro con el mundo, con la vida y con otros cuerpos. Cuerpos que sin duda se enuncian en términos explícitos (por su evidencia en las imágenes que pueden observarse) como también por lo implícito de lo programático de las obras en tanto textos puestos en relación con imágenes o representaciones sugerentes del mensaje que proyectan los discursos. Esta 
poética tiene su razón de ser y sus cruces en una dimensión abstracta: es un hecho en donde acontece el espacio, las luces, las materias, los sonidos, el cuerpo, el movimiento, la intensidad, la energía y la experiencia. Estos elementos están depositados en nosotros a partir de nuestro sentir, de nuestras sensaciones, de lo que hemos vivido, mirado, tocado, escuchado y gustado. Todo esto está y queda en nuestro cuerpo para apreciar y re-conocer el cuerpo en el arte y en este tipo de obras.

Este proceso es de tal intensidad que las cosas pueden ser aprehendidas por cada uno de nosotros en la medida que disponemos nuestro sentir en alianza con los sentidos dinámicos del movimiento de los cuerpos, del murmullo de los colores y en consecuencia, la puesta en juego de los ritmos, los espacios y las fuerzas móviles de la aparente inmovilidad de nuestra época. Como señala Nancy,

sobre el umbral, de repente, se interpreta una escena. Esta escena no está destinada a nosotros, no se despliega para la atención ni para la intención de un sujeto. Todo ocurre con indiferencia hacia el visitante, $y$, al parecer, debe incluso quedar sustraído a quien no sea, ya, un íntimo. Nadie nos mira ni nos invita. En suma, hemos entrado, indiscretos, por la fuerza. Pero esa fuerza de intrusión es la de la escena misma ${ }^{11}$.

En este movimiento de sentidos, la moción, la puesta en movimiento con lo otro, produce el mundo de la obra y el mundo que somos en la obra. Para Nancy,

Esto sólo puede hacerse -si se puede, y este poder y esta posibilidad son lo que está precisamente en juego- a condición de poner al descubierto la estructura del sujeto: su sub-jetidad, su

11 Nancy, Jean Luc (2002). Un Pensamiento Finito. Barcelona, España: Anthropos, p. 85 . 
ser-bajo-sí, su ser-dentro de sí, por consiguiente afuera, atrás o delante. O sea, su exposición. El "develamiento" de un "yo" no puede tener lugar más que poniendo esta exposición en obra y en acto: pintar o figurar ya no es entonces reproducir, y tampoco revelar, sino producir lo expuesto-sujeto. Producirlo: conducirlo hacia delante, sacarlo fuera ${ }^{12}$.

El cuerpo en la obra de Alfredo Jaar, hace aparecer la invisibilidad y el silencio de aquello que es impulsado desde el sentido del cuerpo-obra. En los cuerpos proyectados desde la luz y en las intensidades de esa escena, la obra expresa el sentir del cuerpo sentiente. Sentirse sentir en la misma obra, la que a su vez, toca el firmamento, la tierra, la superficie de un límite que expone la propia exposición de un espacio y de aquella poética, sobre y en el cuerpo. En gran parte de la obra de Jaar, la enunciación del cuerpo radica precisamente en su invisibilidad, en la ausencia y obliteración de la corporalidad, pero que sin embargo el gesto estético-político hace aparecer en el espectador la sensación de estar vinculado con el cuerpo y los cuerpos expuestos.

Además de "Lights in the City", se podría pensar en las referencias dadas a otras instalaciones como: El Lamento de la Imágenes (2002), la cual recordaría la violencia permanente a la que está sometido el continente africano, particularmente Ruanda como interés del artista. Una pantalla enceguecedora de luz blanca iluminaba a los observadores en la sala de exhibición, interviniendo sus códigos de visibilidad y apelando a una percepción que demandaba afectivamente un comportamiento distinto. Lo mismo ocurre con las obras Real Pictures (1995) y Untitled (I997) al reiterar la operatoria en los soportes de las propuestas visuales: luces que proyectan el sentido de las imágenes complementadas con textos y su alusión a cuerpos invisibles, pero que logran sentirse

12 Nancy, Jean Luc (2006). La Mirada del Retrato. Argentina: Amorrortu, p.I6. 
en el observador por aquel efecto de sensibilidades que provocan los materiales y las luminarias ${ }^{13}$. Como sostiene Sandra Accatino,

La contraposición entre zonas de oscuridad y luz, el empleo de agua o espejos sobre la superficie del pavimento o en las paredes, crean, además, una impresión de inestabilidad que compromete la forma cómo el espectador se desplaza en el espacio, exigiéndole reacomodar sus sentidos y pidiéndole actuar con cautela y lentitud. Así como los sujetos de las obras de Jaar han sido vulnerados y pasados por alto, los trabajos de arte vuelven vulnerable al espectador, y al hacerlo restituyen a los

13 Brevemente describo las obras referidas: El Lamento de la Imágenes (2002) corresponde a una instalación que consiste en un oscuro pasillo en donde se instala al principio tres textos alusivos al tema de la administración de las imágenes. El primer texto describe el doble enceguecimiento de Nelson Mandela: deslumbrado por la luz en la fotografía de su liberación y cegado por el destello del sol sobre la piedra caliza en las minas donde cumplió parte de su presidio. El siguiente texto se refiere al entierro en una mina de piedra caliza de millones de imágenes fotográficas adquiridas por una compañía de Bill Gates. Entre las fotografías que el texto menciona, se encuentra una de Mandela en prisión. El último texto alude a la compra, por parte del Ministerio de Defensa de los Estados Unidos, de los derechos de todas las imágenes satelitales de la guerra de Afganistán (Catálogo SCL 2006). Al final de la primera sala una gran pantalla que emite una luz blanca de enceguecedora potencia. Real Pictures (I995) comprende un total de 550 positivos de fotografía que reproducen una selección de sesenta imágenes de los campamentos de refugiados, de los lugares donde se perpetraron masacres y destrucción de ciudades en Ruanda. Cada una de las imágenes fue colocada en una caja recubierta con tela negra, y sobre esa tela se serigrafió en blanco una descripción de la imagen, individualizando la fecha, el nombre de las personas y de los lugares que aparecen retratados y las circunstancias en las que se tomó la fotografía. Luego, las cajas fueron apiladas en bloques o extendidas sobre el suelo, dejando a la vista sólo la descripción como recordatorio de un cementerio (Catálogo SCL 2006) y Untitled (I997) cajas luminosas que hasta ese momento habían servido a Jaar de soporte para mostrar sus imágenes aparecen esparcidas, dadas vueltas contra el piso y la pared. En la sala, lo único que brilla es la luz que se asoma desde los dispositivos hacia el exterior de las estructuras. 
acontecimientos, las personas y las cosas aludidas, el tiempo que requieren para ser vistas. Aunque la escena original no pueda nunca ser reconstituida y los hechos y los sujetos aparezcan siempre velados, escindidos, aplazados y ocultos, la imagen mental que el espectador es conminado a elaborar a partir de su propia experiencia puede transformar a las obras, a los acontecimientos y a las personas en ellas contenidos en eventos duraderos y definitivos en su memoria ${ }^{14}$.

Lo que las obras de Alfredo Jaar expresan, son una manera de emanciparnos de la intelección (como nuestras capacidades racionales) y recorrer la idea subyacente en el cuerpo sentido y tocado, que toca y hace del sentir su exposición al límite de nuestros sentidos. Hemos señalado que Jaar utiliza en gran parte de sus creaciones, el recurso de luminosidad para iluminar espacios y contextos particulares (arquitectónicos, objetuales, audiovisuales), para presentar escenas de enunciación de cuerpos, que se comportan como improntas de la corporalidad invisible de la marginalidad y del sufrimiento. Dicha enunciación transita ya sea desde la evidencia de imágenes expuestas -que recordarían rostros y cuerpos de la pobreza o del desencantocomo también en los textos complementarios que se presentan como orientaciones emotivas y complementarias a las representaciones de imágenes exhibidas.

Prácticamente todas las obras aludidas enuncian un mensaje y presentan los cuerpos por medio de haces de luces de diversos tamaños, estructuras y potencias que supuestamente tenderían a perturbar la visión impertérrita del espectador. Una suerte de visibilizar lo invisible del silencio de aquellos sufrimientos y también como una forma de testimoniar que el hombre en su marginalidad existe y padece ante el olvido de una humanidad que no se conmueve con los dramas humanos. Por este mismo reitero que entre sus obras más emblemáticas

14 Accatino, Sandra (2006). Estrategias de Visibilidad. Barcelona, España: Actar, p.2 I 5 
que han utilizado evidentemente este vector, se pueden señalar: Real Pictures - 1995, Untitled - 1997, Señales de Vida - 2000, SköghallKonsthall - 2000, El Lamento de las Imágenes - 2002, El Silencio de Nduwayezu- 2006, entre otras15.

En la obra de arte contemporánea aunque centre la atención del observador en la forma como está realizada la representación de la realidad, siempre existirá un rasgo de indecibilidad, una representación de la representación que se invisibiliza frente al espectador. Lo indecible o lo invisible de una obra no radica en el mero supuesto interpretativo que el sujeto ejerce para decodificar la imagen -una manera de completar la representación expuesta según conjeturas que el sujeto puede realizar en torno al signo y su significación- sino que en la posibilidad que el sentido no significante nos sorprenda antes que las palabras y el pensamiento como la extrañeza que provoca el tacto del sentir en su flujo de intensidades para la aparición y producción de nuevos significados. El sentirse tocado ha provocado una afección que sin duda constituye una presencia sensible (de ahí la extrañeza en el sujeto) no como una mera virtualidad mentalmente representativa sino por el hecho de ser tocado desde el límite del pensamiento. Este hecho puede

15 Describo las obras aludidas en este párrafo: Señales de Vida (2000) en la ciudad de Lyons- Francia Jaar proyecto durante tres días y sobre la fachada del Hotel de Ville los nombres de diez lugares donde ocurrió el genocidio en Ruanda. Francia hasta la fecha reconocido oficialmente todavía la participación que tuvo en los hechos en cuanto al suministro de armas para los genocidas (Valdés Adriana, Arte y Política). Sköghall Konsthall (2000) en la ciudad de Sköghall - Provincia sueca de Värmland, el artista construyó un museo de papel el invitó a jóvenes artistas locales a exponer para que 24 horas después de inaugurada la muestra, se incendiara el museo testimoniando el bajo interés de la ciudad para promover el desarrollo artístico de las nuevas generaciones y El Silencio de Nduwayezu (2006) La obra comienza por el recorrido de un texto iluminado de aproximadamente cinco metros de largo acerca del genocidio en Ruanda. Al entrar a un segundo espacio, se ve una enorme mesa de luz sobre la que se encuentra un millón de dispositivas. Examinándolas, se descubre que todas son idénticas y corresponden a los ojos de Nduwayezu, un niño ruandés que fue testigo del asesinato de sus padres. La comunidad internacional no quiso ver ni tampoco actuar ante el genocidio que en I994 costó más de un millón de vidas en menos de cien días (Catálogo SCL 2006). 
relacionarse con el sentido que provoca la iluminación en las obras de Jaar, al proyectar justamente aquello que no se observa pero que se carga con otros sentidos: el sentir la proyección en el propio cuerpo en la búsqueda, el deseo o la voluntad de sentido. Cito a Nancy:

En verdad, el rasgo notable de muchas obras de la actualidad no está en lo informe o en la deformidad, en lo repugnante o en lo "cualquiera", sino en la búsqueda, el deseo o la voluntad de sentido. Se quiere significar: el mundo y lo inmundo, la técnica y el silencio, el sujeto y su ausencia, el cuerpo, el espectáculo, la insignificancia o la pura voluntad de significar. Una búsqueda de sentido es el leitmotiv (más o menos consciente) de quienes olvidan, como el Wagner de Parsifal, que la estructura de la búsqueda es una estructura de huida y pérdida, en la que el sentido deseado pierde poco a poco toda su sangre16.

Por cierto la obra de Jaar, como cuerpos puestos en movimiento, constituye un verdadero paradigma de lecturas, como un texto que espera ser descifrado no precisamente desde la evidencia que se expone, sino por todo aquello que provoca una afección que no puede ser racionalizada inmediatamente. La experiencia del cuerpo se traduce y se concreta en la obra y en su relación con el espacio-espacialidad. Esta vivencia y experiencia se mantiene latente y vinculante en dos dimensiones: el espacio del cuerpo y el cuerpo en el espacio representacional de la obra, además de todas aquellas en las cuales el artista ha utilizado imágenes, ya sea fotografías, afiches, luminarias al modo clásico de proyección de información o publicidad.

Jaar representa directa o indirectamente el cuerpo por medio de la relación entre imagen y texto construyendo espacios escenográficos

16 Nancy, Jean Luc (2008). Las Musas. Buenos Aires, Argentina: Amorrortu, p. I 24. 
colmados de sentidos para los espectadores. En algunos casos los cuerpos en las obras son evidentes (fundamentalmente fotografías iluminadas con ciertas particularidades), en otros se sugieren por medio de estructuras e instalaciones que se sustentan en el uso de brillanteces y proyecciones luminarias cargadas de enunciaciones por descifrar. Las luces utilizadas por el artista -en la mayoría de las obras- se comportan como el medio en que el cuerpo, el texto o los espacios son proyectados lumínicamente para la provocación de una o más afecciones.

En este sentido su obra refleja el profundo rechazo a la parodia representacional que capitalistas diseñadores, publicistas, audiovisualistas y artistas ligados al mercado espectacular han dado a las representaciones de imágenes artísticas. Bajo estas condiciones la sutileza del consumo o la fetichización de aquellas -valor exhibitivo actual- ha socializado el cuerpo y su representación estética como un ente que nada contiene, nada soporta ya que todo ha sido expuesto en lo efímero de lo inmediato. En su opuesto, la incorporación que realiza Jaar de temáticas y formas de concebir la obra en sus soportes y exposición, ha generado el despliegue de nuevas sensibilidades que creativamente han posibilitado la proyección del cuerpo en su invisibilidad desde los soportes y acciones lumínicas que sin duda pueden tocar el cuerpo del espectador. El toque que el sentido de las obras provoca en la piel del espectador, no es más que el fundamento para que el cuerpo sienta el llamamiento de la emoción desde su propio límite. El cuerpo desprende del gesto su condición de límite que espacia su propia ex-posición al borde. Por ello nos toca y nos susurra el lenguaje propio de los cuerpos en con-tacto. Sin palabras, sin significación, solamente con la escritura de $e l$ cuerpo en movimiento hacia el afuera. 


\title{
2.- La locura del propio cuerpo: lo interno de lo externo
}

\begin{abstract}
Si caminamos, como no podemos hacer, a lo largo de lo interno, nos encontramos sobre la otra vertiente, sobre lo externo. Pero si después quisiéramos retomar la misma vertiente y, no pudiendo estar dentro, creyésemos habernos encontrado en lo externo, de nuevo estaremos en la otra parte. No logramos capturar al otro convirtiéndolo en un alter ego, aunque esto es lo que en primer lugar intentamos hacer. Pero no logramos ni siquiera borrar el yo ni desequilibrándonos completamente sobre el otro. El cuerpo es una alteridad, pero que se repliega sobre lo interno. ¿Lo interno de lo externo? ${ }^{17}$
\end{abstract}

Pier Aldo Rovatti

La cita de Rovatti es elocuente para las reflexiones de este tema. Existe un punto de encuentro entre la propia interioridad del cuerpo -tradición fenomenológica- y todo aquello que la sensación cautiva como tacto desde el exterior del cuerpo -tradición deconstructiva-.

Esta puntualidad que marca el límite entre lo interno y lo externo -punto inestable de equilibrio- estaría dado por la interrupción que el sentido despliega hacia un "adentro" del propio cuerpo, como una estancia de lugares comunes entre un aquí y un allá. Una suerte de movimiento permanente que Rovatti lo retoma de la banda del matemático Moebius. Esta metáfora que permite pensar el cuerpo como una oscilación entre lo interno y lo externo, inquieta las significaciones

17 Rovatti, Pier Aldo. La Locura del Propio Cuerpo. En Cartografías del Cuerpo (2004). España: Cende, p. I40. 
tradicionales al tener que situarnos desde la simultaneidad de una doble mirada. Como entender entonces la pregunta del autor, ¿lo interno de lo externo? o si se quiere también, ¿lo externo de lo interno? Por el momento, dicha interioridad nos vuelve al cuerpo fenomenológico, al cuerpo vivido, a la experiencia de ser cuerpo y sentirse sentido como tal en aquella dimensión de lo interno.

El cuerpo se encuentra en el mundo no como un objeto para la ocupación de un lugar cualquiera, sino como la forma en que logramos conocer las cosas y sentirlas. De mi cuerpo depende que vaya a las cosas mismas para hacer vivir un mundo y tener un mundo. Sin embargo, si tenemos que volver a las cosas debemos disponer de un acceso a las cosas, debemos ser capaces de encontrarnos con las cosas de alguna manera. ¿Cómo? Las cosas están realmente frente a nosotros, estamos en contacto con ellas, están ahí, en su realidad corpórea. Y si tenemos las cosas en su realidad corpórea ante nosotros, basta con tomarlas así como se dan. No disponemos de ningún otro modo para confirmar las cosas. Única y exclusivamente tomarlas en las condiciones en que se nos ofrecen ante nuestra percepción y nuestro cuerpo. Es como una manera de abrir un espacio y entrar hacia esa experiencia donde el cuerpo sería esta especie de mediación entre y con las cosas. Por cierto, dicha mediación que realiza el cuerpo, necesita de la mirada, de la visión como forma de apropiación de lo que ve, como manera de abrir esos mundos posibles. Para Merleau-Ponty, el misterio reside en que el cuerpo es a la vez vidente y visible. Para este autor, el sentido de la visión sería el medio dado para ausentarse de sí mismo, una inquietante relación que entre-cruza y fusiona, el vidente y lo visible, entre quien toca y lo tocado, entre el que siente y lo sensible. Cito,

Así, si lo visible puede llenarme y ocuparme es únicamente porque yo, que lo veo, no lo veo desde el fondo de la nada, sino desde su propio centro, yo, el vidente, soy también visible; lo que da peso, espesor, lo que constituye la carne de cada color, de cada 
sonido, de cada textura táctil, del presente y del mundo es que quien lo capta siente que emerge de ellos como por una especie de enrollamiento o de duplicación, fundamentalmente homogénea a ellos; siente que es lo sensible mismo encarnándose en él y que, inversamente, lo sensible es a sus ojos como su doble o como una prolongación de su carne ${ }^{18}$.

En esta verdadera encarnación que el cuerpo realiza de las cosas, reconocemos su existencia para entrar en el mundo y donarnos la experiencia de sentirnos afectados en nuestras posibilidades. Por esto lo dado por el mundo y los otros cuerpos, debe darse como fenómeno originario, como aquello que se da no en su re-presentación, sino en su presencia realmente presente. La constatación fenomenológica de Merleau-Ponty radica en que el cuerpo "ve" por medio de la unidad de los sentidos y en el movimiento de las palabras que traducen. Por cierto, podemos decir que tenemos la sensación de escuchar los colores y ver los sonidos en la medida en que éstos repercuten nuestro modo de existir, en nuestro cuerpo como el estar-en-el-mundo.

La sensación solamente puede ser anónima porque es parcial. Quien ve y quien toca no es exactamente yo mismo, porque el mundo visible y el mundo tangible no son el mundo en su totalidad. Cuando veo un objeto siempre experimento que aún hay ser más allá de cuanto actualmente veo, no sólo ser visible, sino incluso ser tangible o captable por el oído -y no solamente ser sensible, sino también una profundidad del objeto que ninguna captación sensorial agotará19.

Con estas breves ideas vuelvo a Jaar para entender que en su obra se nos aparece el enigma del cuerpo en plenitud. Desde nuestra interio-

18 Merleau-Ponty, Maurice (I970). Lo Visible y lo Invisible. Barcelona, España: Seix Barralp. I 45 .

19 Merleau Ponty, Maurice (I997). Fenomenología de la Percepción.Barcelona, España: Península, p. 232 
ridad -quizás como sensación y percepción-, comienza a producirse una interpelación por el hecho de ser hombres afectivamente arraigados al mundo. Para Patôcka esta condición sería una posibilidad real ya que,

sólo con el fundamento de lo que hace que ciertas impresiones puedan serlo verdaderamente, es decir, que puedan apelar a la condición de nuestro arraigo originario en el mundo, sólo con ese fundamento puede ser que posteriormente lleguen a representar algo, que sean capaces de decirnos algo originario ${ }^{20}$.

Existe una especie de presencia que algo ocurre en lo que veo y que me mantiene cautivo y cauteloso en el contacto con la realidad obra. Una profundidad intensiva donde las cosas me dicen algo, donde la obra revela unos cuerpos para permitirme el comprender el propio cuerpo bajo un contacto más profundo. Pensemos por un momento en "Lights in the City": con ella, el acercamiento al fenómeno de la obra, esta mediado por nuestro cuerpo como una urdimbre de los sentidos que permiten poner "entre paréntesis" los prejuicios de la realidad exhibida. Complemento esta idea con palabras de Husserl:

Cada yo encuentra en su entorno, y frecuentemente también en su entorno actual, cosas que mira como cuerpos, pero enfrentados profundamente al cuerpo "propio" como cuerpos ajenos, de tal modo que a cada uno de ellos corresponde nuevamente un yo, pero otro yo o un yo ajeno (el yo mira esos cuerpos como "portadores" de sujetos-yo, pero no ve los yoes ajenos en el mismo sentido en que se ve o encuentra a sí mismo en su propia experiencia ${ }^{21}$.

20 Patôcka, Jan. Introducción a la Fenomenología. España: Herder, p. I74.

21 Husserl, Edmund (1994). Problemas Fundamentales de la Fenomenología. Madrid, 
Este otro yo de las instalaciones de Jaar, apela a nuestra interioridad, a nuestra afección por el mundo y con el mundo de otros cuerpos distantes y distintos al mío. Una suerte de cuerpo rememorado, en recuerdo y en presencia, que no tendría otra significancia que la dispersión de sus signos, el cara a cara con la locura de lo propio. He aquí la otra oscilación del movimiento, la indeterminación del signo para escribir el cuerpo como una exposición no significante. Una otredad de la locura que Jaar provoca con la obra. Didi-Hubermann, comentando la pragmática del artista y refiriéndose al trabajo de imagen que realiza, nos señala que:

(...) la imagen creada por el artista es algo completamente diferente a un simple corte practicado en el mundo de los aspectos visibles. Es una huella, un surco, un coletazo visual del tiempo que ella quiso tocar, aunque también de aquellos tiempos suplementarios -fatalmente anacrónicos, heterogéneos- que ella no puede, en tanto que arte de la memoria, dejar de aglutinar. Es la ceniza mezclada, más o menos cálida, de una multitud de hogueras ${ }^{22}$.

Preciso con cierta cautela desde la obra referenciada: la locura está en la proyección luminaria de aquellos cuerpos que transitan por aquella "banda" como una visión del límite o quizás, al límite. Al acercarnos al exterior con la mirada, se comienza a tocar el borde externo del cuerpo y se precipita el esperado cierre de la encarnación significada de las cosas. Nancy pregunta al respecto: “ ¿No sería preciso que hubiese no-acceso, impenetrabilidad, para que haya también acceso, penetra-

España: Alianza, p. 5I.

22 Didi-Huberman. La Emoción no dice "Yo". Diez Fragmentos Sobre Libertad Estética. En Alfredo Jaar. La Política de las Imágenes. Adriana Valdés, Editora General, Metales Pesados, Santiago, Chile, 2008, p. 5 I 
ción?, ¿qué entonces haya no-sentido o, sobre todo, fuera de-sentido para que hubiese sentido?"23.

¡He aquí la locura!: Jaar deja abierta la presencia del cuerpo al exponerse en la luz la afección de sentirse afectado por un afuera, por la interrupción que el cuerpo posibilita en el sentido. Las obras que Jaar trabaja desde la luz, no exponen solamente los significados sobre referencias a cuerpos indigentes, sino como la singular extrañeza de la presencia corporal como un pre-sentido de ella misma. Como sostiene Zúñiga,

la idea del artista, en cierta manera, era denegar el puro valor exhibitivo de la victimización a que estas personas quedan reducidas en el contexto de la denuncia pública de la situación que padecen. Jaar se propuso entonces, visibilizar esos cuerpos borrados, pero en cuanto borrados ${ }^{24}$.

Esta particular suspensión de la forma de entender el sentido de la obra, genera una fractura en las significaciones o interpretaciones sobre las creaciones del artista. Es más, pensar desde el sentido expuesto del cuerpo no sería si no pensar el cuerpo como interrupción de todos los sentidos significantes. La luz en Jaar viene a la vista como desde afuera, como un viaje en tacto de luminosidad que perturba la visión del espectador y lo mantiene en contacto al mirar. La brillantez no revela explícitamente los cuerpos referidos, sino que su propia irradiación. Es ya el límite para que se produzcan otras interpretaciones, otras sensaciones de mayor intensidad. Al respecto, Griselda Pollock introduce

23 Nancy, Jean Luc (2003). El Sentido del Mundo. Buenos Aires, Argentina: La Marca, pp. Ioo.

24 Zúñiga, Rodrigo (2008). La Demarcación de los Cuerpos. Santiago, Chile: Metales Pesados, pp. I05. 
una interesante noción que soporta muchas de las creaciones de Jaar y que determinaría esta suerte de estar en contacto al mirar:

una suerte de movimiento (coreografía) que las imágenes producen. Sostiene en este sentido, que el trabajo de Alfredo Jaar no consiste en producir imágenes, sino en la creación y coreografía del encuentro entre el espectador y éstas, y de la consiguiente reflexión del espectador, en una cultura saturada de imágenes... ${ }^{25}$.

También Jacques Rancière, refiriéndose a la obra general de Jaar, sostiene que el artista, de alguna manera logra producir el sensible y el sentido en el lugar de otro, un nuevo espacio construido por estas substituciones. Eso comienza por supuesto por las palabras, retiradas en el sentido de la audiencia para ser afectados a la mirada, no solamente como señales de un significado sino como formas visibles ${ }^{26}$. Los cuerpos presentados en la invisibilidad de la luz, tocan la posibilidad de algún cierre, y en ese preciso acto, tocar lo que está cerrado es ya abrir el enigma del cuerpo. Como sostiene Zúñiga "Hacer luz: abrir una grieta, precipitar una crisis, dar a pensar. Hacer luz, en este caso, en el mecanismo petrificado de la significación, de la representación cultural que se detenta y se naturaliza. Hacer luz para "comunidades carentes de imágenes..." 27 .

Algunos breves comentarios a propósito de lo que señala Alfredo Jaar al respecto:

25 Pollock, Griselda. Sin Olvidar África. En Alfredo Jaar. La Política de las Imágenes. Adriana Valdés, Editora General, Metales Pesados, Santiago, Chile, 2008, p. I 27.

26 Cfr. Rancière, Jacques. Le Théâtre des Images. Texto sugerido en el curso "Escrituras Sobre Arte”, impartido por Adriana Valdés, Doctorado en Filosofía, mención Estética, 2007.

27 Zúñiga, Rodrigo (2006). El Sitio y la Fórmula. En Catálogo JAAR SLC. Barcelona, España: Actar, p. I I9. 
Siempre hay un elemento de luz: lo necesito. Es verdad que está enmarcada en un espacio muy oscuro. Siempre me pregunto cuánta luz quiero dejar ver: es un elemento clave del programa. Es una cosa objetiva, un elemento de esperanza. En cada obra está. En algunas no es tan evidente, pero está. Gracias a esta luz puedo seguir haciéndolas ${ }^{28}$.

La luz de las obras, vendría a ser un imperativo de su propia pulsión de visibilización de los cuerpos. Cualquier identificación del sentido como significación en esta visualidad, opaca cualquier condición de un posible para nuevas circulaciones de significados. Dar a pensar nos dice Zúñiga, ya que hay algo que verdaderamente acontece. Nancy señala que

hay, pues, algo que pensar -el acontecimiento- cuya naturaleza misma -el acontecer- no puede sino surgir de la sorpresa, no puede más que pillar al pensamiento por sorpresa. Hay que pensar cómo el pensamiento puede y debe sorprenderse -y cómo quizá, es esto mismo lo que le hace pensar. O incluso cómo no habría pensamiento sin acontecimiento de pensamiento ${ }^{29}$.

Confrontando al filósofo, el peso de la luz en la obra, ha puesto al pensamiento en una apertura y en su desborde en el sentido de estar fuera de sí, como manera en que el cuerpo fuerza al pensamiento a ir más lejos. Este toque del cuerpo corresponde al sentir. Pero siguiendo a Nancy,

28 Alfredo Jaar, Conversaciones en Chile, p. 87.

29 Nancy, Jean -Luc (2006). SerSingular Plural. Madrid, España: ArenaLibros,p. I79. 
¿qué es esto del tacto de lo incorporal y del cuerpo? Necesariamente, eso tiene que ver con cierta interrupción del uno por el otro. Hace falta que lo incorporal sea interrumpido cuando toca el cuerpo y hace falta que el cuerpo sea interrumpido, o abierto, cuando toca lo incorporal o cuando es tocado por ello ${ }^{30}$.

Por esto los cuerpos que se exponen en las obras de Jaar, nos hacen sentir intensidades comprometedoras. No está demás dar otros ejemplos de sus obras que de alguna manera relacionan visibilidad(imagen) -invisibilidad(sentir)- luminosidad (cuerpos), en sus proyectos: "Un Logo para América” (I987), "Rwanda Rwanda” (I994), "El Silencio de Nduwayezu" (I997) entre otras ya citadas y comentadas con anterioridad $^{31}$.

30 Nancy, Jean-Luc (2003). “Corpus”. Madrid, España: ArenaLibros, p. 96.

31 Estas obras siguen patrones comunes en la mayoría de los proyectos artísticos de Alfredo Jaar. Insisto lo dicho al comienzo de la investigación: La mayoría de las obras del artista, se sostienen en tres principios comunes a la poética de denuncia: En primer lugar, el tratamiento que opera desde la iluminación de ellas -sean éstas imágenes de cuerpos en proyección, palabras que brillan en soportes de neón y propiamente la brillantez minimalista- revelan la urgente necesidad de hacer pública la condición de millares de hombres que viven en la marginalidad del sistema capitalista. Esta verdadera “cuestión social” de la imagen (poética de la luz), reclama permanentemente la necesidad de representación de aquello impresentable para cualquier régimen político: la condición de invisibilidad de aquel resto de humanidad pendiente. En las instalaciones se aprecia también, una íntima relación entre las palabras, textos, declaraciones, frases discursivas, y las imágenes propiamente tal (proyecciones de video, fotografías, recursos audiovisuales). La mayoría de ellas, presentan una relación de sustitución y complementariedad entre una y otra. La enunciación textual señala justo aquello que la imagen silencia, y el texto visual, aloja en su sentido, lo prohibido de lo impresentable como una acción programática de opacidades y testimonios silentes en presencias/ausencias. Las obras pueden transitar desde experiencias micro visuales a monumentalidades expuestas. Por lo general, el uso de espacios públicos, el volumen de lo arquitectónico, la "grandiosidad" de la iluminación, delatan en Jaar, la determinación de visibilizar a "gran escala" y en espacios específicos, a todos los excluidos y oprimidos del mundo 
La luminosidad de este verdadero acontecimiento, sitúa un lugar, precisa un espacio, se decide un aquí: las intervenciones públicas ocurren en el mundo real, y me mantienen real (Jaar). El mantenimiento es una decisión de ser obra en un lugar determinado por su interpelación. Este en ya envía una seña a los habitantes y espectadores de las instalaciones como inclusivos al espacio en intervención. Un devenir siempre sentido, siempre cuerpo que siente el consentimiento del espacio. Para Oyarzún, las intervenciones de aquellos espacios dejan abierto el sentido del misterio de ese en -soberano del silencio. Cito al autor:

La obra se yergue incorporando en sí el espacio y las condiciones de tal erguimiento: en su más poderosa instancia -la "gran obra"-, alcanza el vigor de lo originario, lo fundante. En ella toda opacidad pareciera quedar vencida. La transparencia inapresable de un significar sin límite debiera señalarla, y si ha de haber un misterio, no será otro que el de esta asombrosa capacidad significativa. Hablemos, pues, en lugar de una escisión entre soporte y obra, de una entre soporte y significado, física y meta-física de la obra (...) En el arte se hace sentir esa reticencia. La instalación es una de sus variantes más lúcidas $(\ldots)^{32}$.

como forma testimonial y ética de ser parte de aquel mundo (pág. I3).

32 Oyarzún, Pablo (2003). El Rabo del Ojo. Prólogo Para Una Muestra de Arte Site Specific. Santiago, Chile: Arcis, p. 83. 


\section{CAPÍTULO III}

\section{ALFREDO JAAR: LA ENUNCIACIÓN DEL CUERPO}

Cuerpo hay ahí donde una terrible, imperiosa, inaguantable necesidad se impone, se presenta -ella- Cuerpo es necesidad: no todo cuerpo es necesario, pero todo lo necesario es cuerpo. Cuerpo hay ahí donde un deseo, que se oculta para que se lo descubra, tiembla ser descubierto, tiembla no ser descubierto (...) Cuerpo es pensamiento necesario.

Patricio Marchant ${ }^{33}$

\section{Preámbulo crítico}

Los cuerpos en el mundo se mantienen en un contacto que puede ser estremecedor causando placer o causando terror. La maldad, la crueldad, la violencia de un cuerpo a otro y la explotación del cuerpo como servicio al capital económico en tiempos mercantiles, produce un cuerpo desplegado a producir violencia, mercancías y para aumentar la economía del que explota y no del explotado. Nancy deja explícita esta condición del cuerpo moderno en la supremacía del capital, señalando lo siguiente:

33 Marchant, Patricio, “Discurso contra los Ingleses”, en Revista de Crítica Cultural, $\mathrm{Nro}^{\circ}$ 2, noviembre de I99I, Stgo, p. 4 
Los cuerpos de fábrica, de taller, de obras, de oficina, partes extra partes que componen por medio de figuras y movimientos con todo el sistema, piezas, palancas, embragues, empaquetados, escotaduras, encapsulados, fresados... sistemas servidos, servidumbres sistémicas, almacenamientos, controles, pulverizaciones, perforaciones, cableados, canalizaciones, cuerpos canalizados únicamente hacia su equivalente monetario, únicamente hacia la plusvalía de capital que se reúne y se concentra ahí... Capital quiere decir: cuerpo traficado, transportado, desplazado, recolocado, reemplazado, en posta y en postura, hasta la usura, hasta el hambre... De esta manera, capital quiere también decir: sistema de sobre-significación de los cuerpos. Nada es más significante/significado que la clase y el esfuerzo, y la lucha de clases. Nada escapa menos a la semiología que los esfuerzos padecidos por las fuerzas, la torsión de los músculos, de los huesos, de los nervios. Mirad las manos, los callos, la mugre, mirad los pulmones, las columnas vertebrales. Cuerpo asalariado sucio, suciedad y salario como un anillo enroscado de significación ${ }^{34}$.

En la cultura occidental y en nuestra sociedad capitalista, el cuerpo se vende, se explota, se trabaja y se forma como máquina que produce capital. Cuerpo productivo para un mercado que se basa en la explotación de otros, donde la imagen que se publica de los cuerpos es una falsedad inventada para ocultar dicha explotación. El cuerpo modelo de una estética ilusoria no muestran el cuerpo trabajado para producir dentro de su trabajo, un cuerpo doblado, exprimido, vaciado, mutilado, desplegado de su ser de su existencia, puesto en una existencia de mercado.

La libertad del individuo, la libertad de los cuerpos oprimidos y enajenados, nos hace reconocer la potencia de un cuerpo creador. Al

34 Nancy, Jean-Luc. Corpus. Madrid, España: Arena Libros, p. 84. 
ser cuerpos del mundo podemos re- significar el mundo en nosotros mismos dándole un nuevo sentido al mundo, un sentido creado por un sí mismo, gracias a la capacidad que poseemos de percibir el mundo y de apropiarnos de lo que percibimos incorporándolo en nuestra experiencia de vida, por medio de nuestra existencia como ser del mundo y ser en mí mismo.

\section{La presencia de lo impresentable: una propuesta estética}

Cuerpo hay ahi donde un deseo, que se oculta para que se lo descubra, tiembla ser descubierto, tiembla no ser descubierto. Esta breve vuelta a la referencia de Marchant, precisa la necesidad de reflexionar en torno a la producción artística de Alfredo Jaar y su relación con el escenario relacional en que el hombre moderno se hace presente en la sociedad.

Las palabras de Marchant se vinculan con la obra de Jaar, precisamente en lo que nombra la palabra cuerpo, nombre en tanto deseo y necesidad de aparecer en su sentido cuerpo, no como una escritura sobre o del, sino escribir el cuerpo para que su mismidad sea reconocida en la oscuridad. Pensar la obra de arte, esta obra de arte, posibilita la urgencia de hacer del cuerpo una luz, un destello, una brillantez, una presencia en el aparecer de las luces de los cuerpos. De iluminar lo no visible, de escribir la luminosidad precisamente en torno a la ausencia del otro, de lo otro, ausencia pura como señalaría Derrida, y en consecuencia, no la ausencia del cuerpo como objeto de la materialidad, sino la ausencia de todo cuerpo, su ausencia representacional en la presencia, la cual inaugura su propia alteridad. Esta presencia no-visible del cuerpo o de los cuerpos soportados en susurros en la obra "Lights in the City", se transforma en el sentido estético de la creación, precisamente al presentar lo impresentable de la condición humana extrema. El carácter de lo impresentable, manifiesta una zona transgredida y en transgresión de su propio límite estético, ya que al actuar como oposición a la presentación se ubica en la sociedad de manera provocante y sugerente. 
La operación creativa que Jaar presenta, es una especie de "pulsión de intervención política", que excede el límite convenido en las estructuras clásicas de producción artística. ¿He aquí el gesto político?, ¿cuerpo de la invisibilidad como política de un gesto? En uno de los textos introductorios del Catálogo "Jaar SCL 2006", Adriana Valdés sostiene que, (...) no se trata sólo de visualizar, de disponer artísticamente los materiales de una obra, aunque también se trate de eso. Se trata de visibilizar, de hacer visible algo que no entra en los esquemas de pensamiento del espectador, algo que los descentre y los perturbe, algo que aparezca como ajeno... pero al mismo tiempo en cierto sentido seduzca, logre introducir una cuña de inquietud en los sistemas de certidumbres. ${ }^{35}$

Consciente también que existe una comunidad de artistas, que explícita e implícitamente, trabajan como programa de producción de obra, temáticas como las expuestas por Jaar, no es menos cierto que desde las relaciones señaladas en las instalaciones del artista (imagen - cuerpo - luz), se tiende a intervenir no solamente un espacio privado (Galería, Museo, Sala de Exposiciones, etc), sino que también, una trayectoria que expone en lo público, tanto en el volumen monumental de la materia, como en una pequeña diapositiva, el sentido del cuerpo en el mundo. Pensar la creación de Jaar como un reflejo especular negativo, o si se quiere, el "negativo" del reflejo del espejo, tiende a movilizar la mirada y el cuerpo del observador, el cuerpo político del vidente.

Entremos en el análisis de la obra:

Esta intervención artística tiene por objeto informar a la sociedad de la situación diaria de las personas sin hogar. Un flash rojo iluminará la cúpula del Mercado Bonsecour cada vez que un individuo en la necesidad se apoye sobre este disparador. El flash luminoso da prueba así de su presencia creciente en los

35 Valdés, Adriana (2006). Apuntes para una Poética de Alfredo Jaar. En Catálogo "JAAR SCL 2006". Barcelona, España: Actar, p. 50 
refugios de Montreal respetando no obstante su dignidad y su vida privada. ${ }^{36}$.

Este primer fragmento de texto, que es parte de la instalación vinculada a las hospederías, permite entender el aparecer de la vida indigente, que en momentos del cotidiano, "publicita" y manifiesta el ser ignorado de la modernidad, el dolor del olvido. Su estar-en-el-mundo es obra, arte y parte realizada por medio del sentido de la invisibilidad de los cuerpos y de todos los "sin parte" que tocan el sentido no significante del observador. En Nancy, esta condición se manifiesta en que "ver un cuerpo no es precisamente captarlo en una visión: la vista misma ahi se relaja, ahi se espacia, no abarca la totalidad de los aspectos. El "aspecto" mismo es un fragmento del trazado (a)real, la vista es fragmentaria, fractal, con eclipses. Por lo demás, es un cuerpo el que ve un cuerpo". ${ }^{37}$

He allí el gesto político de Jaar. He ahí la estética como acto político y el disenso como acción estética. La audacia de esta impronta está en asumir esta interrogante: ¿Alfredo Jaar vendría a ser un artista sin parte en la mercancía del arte?. Pregunta compleja, en la medida que los detractores de Jaar, sostienen que la producción del artista no sería tal sin un plan presupuestario y una comprometedora participación del capital en la creación e instalación de sus obras. Por cierto, es así, sin embargo sería muy pequeña la discusión si nos acercamos a sus

36 http://www.alfredojaar.net Este fragmento, corresponde a una parte del texto, que se encuentra en las hospederías de Montreal, para las personas sin hogar y que vincula la obra (instalación) con el cuerpo no visible del indigente. Transcribo esta parte, tal como están presentados en los hogares: "Cette intervention artistique vise à informer la société de la situation quotidienne des sans-abri. Un flash rouge illuminera la coupole du Marché Bonsecour á chaque fois qu'un individu dans le besoin appuiera sur ce déclencheur. Les flash lumineux témoignent ainsi de votre présence croissante dans les refuges de Montréal en respectant toutefois votre dignité et votre vie privée ". Ver texto completo en el anexo del ensayo.

37 Nancy, Jean Luc. Corpus. Madrid, España: Arena Libros, p. 37. 
obras desde el privilegio del financiamiento y la cobertura de costos. La toma de conciencia que permiten sus obras, se sostiene no en el precio que cuesta levantarlas, sino que en el valor social que poseen: ¿precio o valor por la obra?

Diferenciemos el gesto político como un valor. Jacques Rancière, en una sugerente entrevista delimita esta operación al señalar que,

(...) la noción de los "sin parte" es la noción de un sujeto político, y un sujeto político nunca puede ser identificado sin más con un grupo social. Razón por la cual digo que el pueblo político es el sujeto que encarna la parte de los sin parte -con ello no decimos "la parte de los excluidos", ni que la política sea la irrupción de los excluidos, sino que la política es, ante todo, la acción del sujeto que sobreviene con independencia de la distribución de las partes sociales ${ }^{38}$.

Cuerpo es pensamiento necesario, dice Marchant. Me pregunto, ¿’para la comunidad social? Parece ser, que paulatinamente esta comunidad, ha vuelto su mirada a la catástrofe de la indolencia y de la indiferencia de los cuerpos que realizan la propia comunidad como cuerpo. Cuerpo no vidente de cuerpos que manifiestan la no videncia del otro. Una suerte de pérdida y de marginalidad que es propiamente constitutiva del nombre comunidad social y política moderna. Se podría sentir en un cuerpo que padece o que comparece frente a un presente sin presencia. Como una substitución de la presencia que ausenta al hombre en todas sus manifestaciones. Podríamos también pensar, en un modo conveniente de relaciones, que permiten sustituir el cuerpo del otro como el objeto de deseo y de producción material. En cada comunidad política, el presente del objeto cuerpo, se traduce en su propio olvido, en la negación que niega su propia existencia y la presencia de otros cuerpos, que se le descubre, que se deja en evidencia su existencia en

38 http://caosmosis.acracia.net/?p=4 I I. Entrevista publicada en la Revista Archipiélago, el $\mathrm{Nro}^{\circ} 73$, marzo 2007. 
el temblar de su descubrimiento. Temblor y necesidad, que para Marchant es también lenguaje y escritura de todo aquello que nombra los límites de la ocultación, los límites de su propio sentido revelado a la comunidad política. Una suerte de cuerpo sin parte, de cuerpo que des-corporaliza la comunidad política como su propiedad productiva.

Es en este contexto, que el gesto político del cuerpo en la obra, se traduce en su acción independiente de los otros cuerpos sociales ya que también a ellos les pertenece. Por esto, los artistas nos obligan a escribir los trayectos y cartografías que una obra de arte puede provocar en una comunidad. Una especie de mandato "invisible" que manifiesta la posibilidad de relacionar la noción de cuerpo en la obra, como vector de una presencia no visible y porque no decir, impresentable para la comunidad social. El acto provocativo que realiza "Lightsin the City", correspondería a su aparecer en la ciudad, teniendo como referencia la invisibilidad del cuerpo sin parte, y por consiguiente, la búsqueda precisamente más allá del sentido, o si se quiere, al retorno del sentido del sentido mismo del gesto político de la obra.

\section{Lights in the City: un testimonio de humanidad}

Siempre hay un elemento de luz: lo necesito. Es verdad que está enmarcada en un espacio muy oscuro. Siempre me pregunto cuánta luz quiero dejar ver (...) Es una cosa objetiva, un elemento de esperanza. En cada obra está. En algunas no es tan evidente, pero está. Gracias a esta luz puedo seguir haciéndolas

Alfredo Jaar ${ }^{39}$

Mencionado está en los inicios de este libro, que la obra corresponde a una instalación realizada en el año I999, sobre la cúpula del “Mercado

39 Alfredo Jaar, Conversaciones en Chile. Op. cit. p. 86. 
Bonsecours" y que se extiende hacia las hospederías de los "homless" de la ciudad.

Recordemos que Montreal, es una de las ciudades más privilegiadas del desarrollo capitalista americano y una de las ciudades más prósperas y bellas del continente. Para Jaar, la elección del lugar no significa cualquier lugar, sino el espacio de ese ahí-lugar, donde la acción estética sería impensada como gesto político.

La visibilidad de estos hombres, sin lugar, sin hogar, tendería a opacar la luminosidad y el esplendor de la ciudad ante el asalto sorpresivo de la suciedad, de lo mal oliente, de la podredumbre, de lo marginal. En la imaginación de Jaar, nace el gesto político de la obra para leer y exponer esta oculta necesidad de visibilidad en el ideario social. El tema de la imaginación no es un dato menor en la concepción del artista. Baste ubicarse en el lugar de Jaar, para pensar que el proceso imaginativo dio origen a esta obra. Parafraseando a Jacques Derrida, la operación de la imaginación creadora, vuelve su mirada a la invisibilidad al interior de la libertad poética. "Se trata aquí de una salida fuera del mundo, hacia un lugar que no es ni un no-lugar, ni otro mundo, ni una utopia ni una coartada" ${ }^{40}$. Así la comunidad quedó intervenida e invertida, quedaba obligada a ver... He aquí también el acto de enunciación de la obra.

Lo poético, en la obra de Jaar, es lo que aspira a hacer que esa visibilización tiemble en el borde mismo de su posibilidad (...) Es lo que más allá de dar información puesta en palabras, crea experiencias visuales que sugieren y hasta fuerzan a "desenmascararse", a exigir los hábitos mentales del pensamiento moderno ${ }^{41}$.

40 Derrida, Jacques (I989). La Escritura y la Diferencia. Barcelona, España: Editorial Antrophos, p. I6.

41 Valdés, Adriana. Apuntes para una Poética de Alfredo Jaar. Barcelona, España: Actar, p. 6I. 
"Un flash rojo iluminará la cúpula del Mercado Bonsecours cada vez que un individuo en la necesidad se apoye en este disparador". ${ }^{42}$. Este segundo fragmento del texto - instalación que cito, cifra una segunda cuestión: el cuerpo marginado se hace luz y el monumento arquitectónico es cuerpo de un calor lumínico que resplandece todos los cuerpos de la marginalidad. Este hacer cuerpo en la luz, esta especie de texto por descifrar, nombra un resto que en su estética logra restar el sin sentido de esta experiencia social.

El otro aparece de su clandestinidad obligada como este OTRO en la alteridad del sentido, se hace aparecer en aquello invisible del acontecimiento y por qué no decir, de la obra realizada en la palabra cuerpo. Justamente, estamos ante el juego del lenguaje imposibilitado de nombrar lo que hay ahí en los márgenes del lenguaje. Homi Babha, nombra en su crítica histórica reciente, lo in-decible del cuerpo-marginalidad como la propia supeditación de la cultura - imperio como signo... "El imperio del lenguaje como sistema de significación -la posibilidad misma de hablar- se transforma en el mal gobierno del discurso: el derecho de sólo algunos de hablar en forma diacrónica y diferenciada, dejando a los "otros" (...) sólo la posibilidad de hablar sintomática o marginalmente" ${ }^{43}$. Estados de margen, borde y frontera, nos hacen preguntar en torno a prácticas artísticas que impulsan el sentido mismo del límite y del conocimiento que presentan. Para Sarat Maharaj,

tales modalidades hacen posible tanto otras maneras de conocer como maneras de conocer lo otro. Se trata de un equipamiento contraepistemológico - un xenoequipamiento hecho para atraer

42 Transcribo el texto en francés como aparece en la hospedería: «Un flash rouge illuminera la coupole du Marché Bonsecour á chaque fois qu'un individu dans le besoin appuiera sur ce déclencheur».

43 Babha, Homi. Luciérnagas Atrapadas en Melaza. Temas de Traducción Cultural. Texto sugerido en el curso «Escrituras Sobre Arte», impartido por Adriana Valdés, Doctorado en Filosofía, mención Estética (UCHILE), 2007. 
y conducir la diferencia, y para habérselas con ella- para medir lo extranjero, lo desconocido, lo ajeno ${ }^{44}$.

Por más que se quiera instalar en la obra, una mirada euclidiana, retiniana, cartesiana o significada, es precisamente, desde su distancia como relato, lo que dona al sentido de la obra, el resto y los restos que no vemos o que no sentimos o que no pensamos bajo los conocimientos tradicionales de la propia visibilidad. Me parece que el sentido de esta obra, radica particularmente en no darle una significación más que añada lo dicho y los dichos críticos, sino de entrar en ese sentido que ella misma es. Ese algo distinto, esas diferencias de algo distante, que más que aquello que pueda identificarse en la distinción y la diferencia, se aparece desde su opacidad, desde su exterioridad y desde su espaciamiento del sentido en los márgenes de su propia materialidad. ¿Es posible pasar por alto el mundo de los cuerpos o de la obra como cuerpo sin retirarse de lo visible?

Lights in the City, toca lo visible de la invisibilidad de este acontecimiento, ya que en su expropiación, el pensamiento queda suspendido sobre el afuera del sentido mismo que nos toca desde la cúpula. En esta operación, se provoca una materialidad productiva ya que la obra como acontecimiento, inscribe el cuerpo que se nombra en la corporización de los pobres del presente. Es así, señala Zúñiga,

como si la mención del nombre alumbrara una presencia, o trajera a la luz al ausente, a la sombra murmurante de ese nombre. Nombre que no es nombrado sino en su propia operación re-significante e in-significante del artificio de hacer luz: abrir una grieta, precipitar una crisis, dar a pensar. (...) Hacer luz para "comunidades carentes de imágenes ${ }^{45}$.

44 Maharaj, Sarat. Xenoepistemias: Instrumental Hechizo (Provisorio) para Sondear (Tantear) el Arte Visual como Producción de Conocimiento y los Regímenes Retinianos. Texto sugerido en el curso «Escrituras Sobre Arte», impartido por Adriana Valdés, Doctorado en Filosofía, mención Estética (UChile), 2007.

45 Zúñiga, Rodrigo. El Sitio y la Fórmula. En Catálogo JAAR SLC. Barcelona, España: Actar, p. I I 8 
Todas las luces, todos los cuerpos, son repartidos en los márgenes de la visualidad. Todos los cuerpos tocan y se tocan. Fuego quemante, que brota de la luz, como si el monumento arquitectónico recordara cada vez sus incendios melancólicos y la reiteración, una y otra vez, de la tragedia del sujeto ausente hecha cuerpo-luz. Dice Jaar que esta muestra del "fuego", la cual significó una tragedia para la cúpula, ahora es una muestra de otra tragedia: la falta de vivienda para los sin-hogar. Y esta vez, tragedia (fuego) está amenazando no a la cúpula, sino a la sociedad en sí misma.

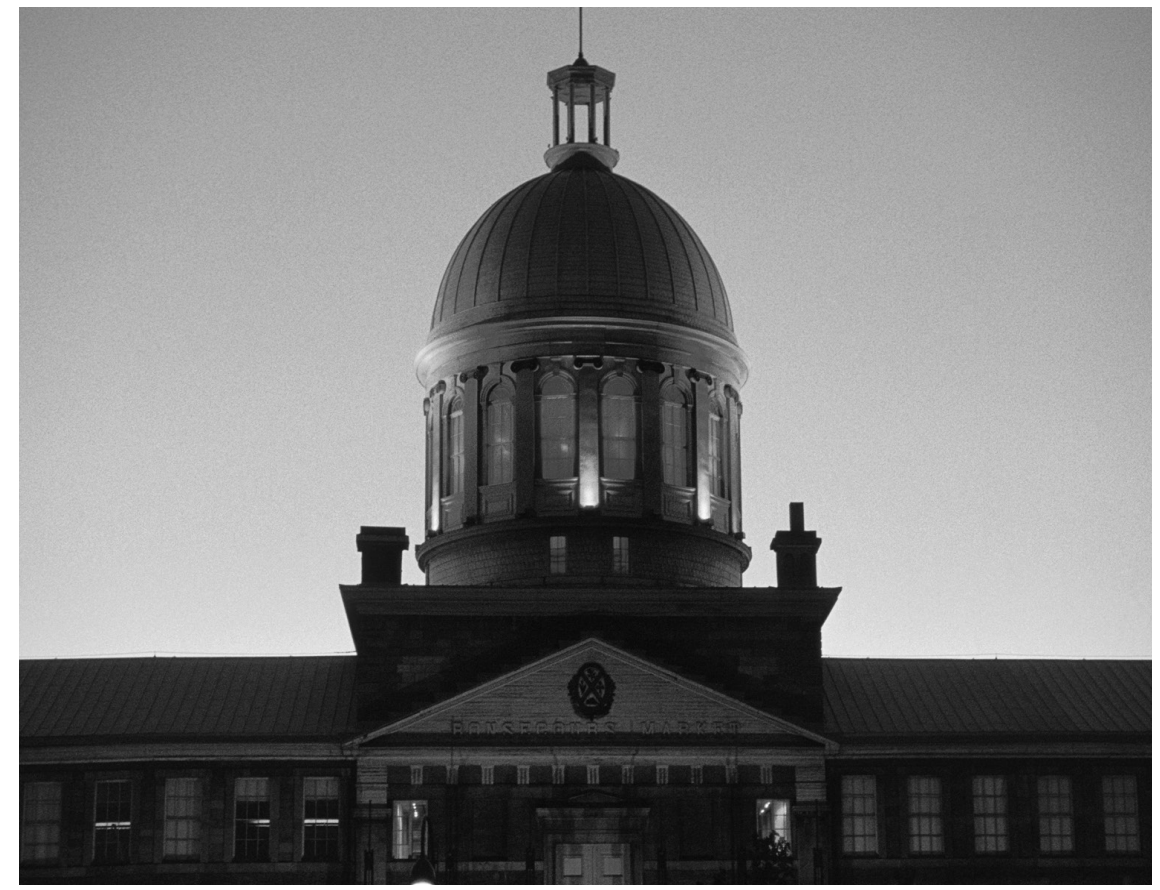

Obra "Lights in the city", Montreal, $1999^{46}$

46 Rodrigo Zúñiga, en su libro "La Demarcación de los Cuerpos”, analiza esta obra con interesantes supuestos sobre la operatoria de instalación de Alfredo Jaar . Cito textual algunos de sus pasajes: "El efecto visual sobre el panorama de la ciudad resultaba altamente sugerente: acompasaba sobre ella un juego de luces que marcaba la presencialausencia de esos cuerpos, como si esas "señales de vida" tuvieran por objeto 
Por cierto, cada señal de luz, emitida por los sin hogar, se transforma en un cuerpo doblegado, en un recuerdo doloroso para la comunidad urbana, pero al fin y al cabo, el destello de la exposición de los cuerpos. La luz, tema tan inquietante para Aristóteles, se hace aquí presente con toda su significación. Cito en su extensión, algunas consideraciones fundamentales del filósofo:

La luz, a su vez, es el acto de esto, de lo transparente en tanto que transparente. Por el contrario, en los cuerpos transparentes en potencia se da la oscuridad. La luz es pues, como el color de lo transparente cuando lo transparente está en entelequia bajo la acción del fuego o de un agente similar al cuerpo situado en la región superior del firmamento. (...) al menos, que lo que se ve a la luz es el color, y de ahí que éste no se vea si no hay luz: la esencia del color, en efecto, consiste en ser el agente que pone en movimiento a lo transparente en acto y la entelequia de lo transparente es, a su vez, la luz ${ }^{47}$.

Sólo vemos cuando el rayo de luz viaja hacia nuestros ojos y produce una serie de sensaciones y alteraciones químicas en nuestros órganos visuales. Si la luz como señalaría Aristóteles, es esta especie de color transparente, los cuerpos presentados y arrojados en la obra aludida, destinados a la inmensidad sensible del espectador, provocan sin lugar a dudas una opacidad, una suerte de sombra desconocida y descolorida que no vendría a ser sino los cuerpos rememorados por Jaar que el mundo moderno sigue olvidando. ¿Cuáles son esas sombras invisi-

conmemorar, en el silencio de la noche, su condición de ánimas en pena, cuya única inscripción efémera estuviera dada por el indicio de esas luces y cuya presencia sólo pudiera cifrarse bajo el signo del peligro". Zúñiga, Rodrigo (2008). La Demarcación de los Cuerpos. Santiago, Chile: Metales Pesados, p. Io6.

47 Aristóteles. Acerca del Alma. Madrid, España: Gredos, p. I93. 
bles que iluminan mi propia sombra? Por cierto, se habla de que los cuerpos poseen sombra aunque sabemos también que la sombra es un fenómeno creado por la luz. Al observar nuestra sombra, vemos un cuerpo proyectado, algo así como otro cuerpo del propio cuerpo, una verdadera puesta en movimiento que moviliza un cuerpo que no está aquí, sino allá y que sin embargo está siempre vinculado con el cuerpo propio, tocándose en el borde de su separación. ¿Serán necesarias estas sombras para que se presente la separación y el distanciamiento de los cuerpos?

Por esto se puede suponer que el cuerpo se ve más allá de sus límites, se reconoce como tal en su sombra tal como si espejara la realidad que lo conforma para habitar el mundo a nuestro lado o a nuestras espaldas. Para Nancy, "la intimidad del cuerpo expone la aseidad pura como la separación y la partida que ella es. La aseidad -el a-si-mismo-, por el sí mismo del sujeto- sólo existe como la separación y la partida de este a-que es el lugar, la instancia propia de su presencia, de su autenticidad, de su sentido" 48 . Con lo anterior, Rancière deja en evidencia lo expuesto cuando señala que,

Alfredo Jaar no suprime las imágenes. Nos recuerda que la imagen no es un simple pedazo visible, una puesta en escena visible, un anudamiento de lo visible y de lo que dice, y también de la palabra y de lo que hace ver (...) Vemos demasiados cuerpos sin nombre, demasiados cuerpos que no nos devuelven la mirada que les enviamos, de los que nos hablan sin que se les dé la posibilidad de hablarnos ${ }^{49}$.

48 Nancy, Jean Luc. Corpus. Madrid, España: Arena Libros p. 29.

49 Rancière, Jacques. Le Théâtre des Images. Texto sugerido en el curso «Escrituras Sobre Arte», impartido por Adriana Valdés, Doctorado en Filosofía, mención Estética (UChile), 2007. 
Ligths in the City mantiene una constante de exposición en el color (rojo) que se proyecta desde su altura, y en este contexto, es inevitable no remitirse a Gilles Deleuze cuando habla del color en la obra de arte, y en particular en la pintura de Bacon. Conscientes que es desde otro lugar lo señalado por el filósofo, la intensidad de este momento del texto amerita su recuerdo: El color vendría a ser como una estructura material espacializante, el acto de la figura, la figura como el hecho, la escena de la figura y el lugar, territorio que encarna el sentido y límite de la obra. La pintura se ha realizado en el toque de la sensación. Por este motivo, el tacto toca lo invisible, logra presentar en la superficie y en el caso de la obra de Jaar, las intensidades de los cuerpos en el devenir de una constante que concierne a la sensación más que a la visión. Deleuze caracteriza al cuerpo como un espacio de movimiento retro-activo, al ser este el acontecimiento del espacio-movimiento-tiempo... ¿cuerpos en la obra de Jaar que se movilizan en el tiempo de exposición de la cúpula?. Sigamos con Deleuze,

el cuerpo espera algo en sí mismo, hace un esfuerzo sobre sí mismo para convertirse en Figura. Ahora donde pasa algo es el cuerpo: él es fuente de movimiento (...) El cuerpo se esfuerza con precisión, o con precisión espera escaparse. No es el yo quien intenta escapar de mi cuerpo, es el propio cuerpo quien intenta escaparse por... ${ }^{50}$.

Esta salida o exposición de los cuerpos en Jaar, se inicia en algún lugar que no es ni un aquí ni un allí con determinación significante. La luz puesta en movimiento por Jaar ¿extra-limita la posibilidad de significación? Parece ser entonces que la relación de los significantes con lo significado en "Lights in the City", se ubica en un espacio en el que ninguna figura intermediaria va a asegurar su encuentro: es dentro del

50 Deleuze, Gilles (2003). Lógica de la Sensación. Madrid, España: Arena, p. 25. 
conocimiento, el enlace establecido entre la idea de una cosa y la idea de otra ${ }^{51}$. Otra mirada, tendría que sentir la brillantez orgánica de lo matérico, las fracturas plásticas de la invisibilidad de los cuerpos, los fraseos imaginarios como cenitales en color y los posibles sensibles de la postura de los cuerpos en el movimiento de la luz. Más allá de estas sensaciones, se des-borda la significación y los cuerpos se escapan por la luminosidad del sentido de ser cuerpo en el mundo.

\title{
4. Cuerpo, sentido y comunidad de cuerpos en "Lights in the City"
}

\author{
Alcanzarse -en el límite- no es comulgar, acceder \\ a otro cuerpo, total, donde todos se funden. \\ Alcanzarse, tocarse, más bien, es tocar el límite \\ donde el ser mismo, el estar-en-común. Nos \\ oculta los unos a los otros, y ocultándonos, \\ retirándonos del otro ante el otro, nos \\ expone a él. \\ Jean-Luc Nancy ${ }^{52}$
}

La cúpula se transformará para la ocasión en un signo socialmente doloroso. (...) Puede ser entonces esta acción una ofensa a la conciencia social $(. . .)^{53}$. Esto es lo que ofrece políticamente Jaar a la comunidad. Con este tercer fragmento de la instalación, abordaremos con mayores

51 Cfr. Foucault, Michel (2005). Las Palabras y las Cosas. Argentina: Siglo XXI, p. 70.

52 Nancy, Jean-Luc (2000). La Comunidad Inoperante. Santiago, Chile: Lom Ediciones, p.II6.

53 Transcribo el texto en francés: "La coupole se transformera pour l'occasion en un signe socialment douloureux. (...) Peut-étre alors cette action fera-t-elle outrage á la conscience sociale». 
precisiones, algunas ideas sostenidas en relación al cuerpo en o de la obra y el correlato con su aparecer en la comunidad social.

La cita interpela dos cuestiones interesantes de leer: Por una parte, el cuerpo -el del indigente- aparece en la cúpula como signo de los cuerpos que representa - la indigencia- en su exposición lumínica-signo de sí y ser-sí-mismo del signo (Nancy). ¡Qué gesto más político! Si pensamos que en su enunciado la indigencia se socializa en el dolor que la luz propaga por la ciudad, me pregunto ¿quién descifra este gesto?, ¿la obra de arte por sí misma?, es decir, ¿`su condición de ser obra de arte? Y desde ahí, ¿`su vinculación con el observador? Me parece que esta creación artística, permite el surgimiento de estas interrogantes. Jaar re-contextualiza el concepto de arte, al provocar una breve pausa que permite al observador, tomar cierta distancia... "algo que descentre y los perturbe”, como decía anteriormente Adriana Valdés. ¿Qué cuerpo es ese capaz de intervenir el cuerpo del otro desde su invisibilidad?, Dejaré por el momento en suspenso esta pregunta.

Una segunda cuestión de la cita, nos pone en evidencia el propósito oculto de la obra: su acción política. Precisamente, la ofensa a la conciencia social, se dirige a la comunidad social como totalidad. Es una acción imperativa que dona a su vez, el sentido de su necesidad. Sería como una recordación ante el llamamiento que la impunidad y el olvido realizan en la indolencia, comunidad ciega ante el cuerpo visible de la pobreza. Lo político está en la luz, como signo del desamparo y de la invisibilidad de los sin-hogar. Y por cierto se encuentra en la comunidad pública, como una comunidad de los otros lejanos, pero iluminados desde la cúpula.

La doble operación estética/política, nos obliga a entrar en el sentido particular de la exposición del cuerpo en el gesto artístico de Jaar, en el entendido que la obra "Lights in the City", evoca una imagen visible de lo invisible que se espacia como cuerpo y en los cuerpos cifrados. Esta evocación reúne a todos los cuerpos de la pobreza y también, a la pobreza como cuerpo que se expone en la luz. Al escribir desde 
esta posición escribimos no en torno a las cualidades fisiológicas, significantes, disciplinares del cuerpo de la pobreza y menos en su condición piadosa o compasiva, sino y siguiendo una cautelosa lectura Nancy, escribimos el cuerpo o si se quiere, la posibilidad de volcar el cuerpo -constituido en la obra- hacia afuera. ¿Es posible realizar así una lectura del cuerpo mismo?, ¿relatar el cuerpo desde su límite? Parece ser que esto es lo provocativo de la obra, la existencia de un cuerpo que toca el sentido desde su inmaterialidad y distanciamiento. "Llega el momento en efecto de escribir y de pensar este cuerpo en el alejamiento infinito que lo hace nuestro, que nos lo hace venir de más lejos que todos nuestros pensamientos: el cuerpo expuesto de la población del mundo" 54 .

Por este hecho, los cuerpos tienen un lugar en un límite donde tocan esta ausencia que proviene de algún afuera, de algún lugar que separa o hace de un extraño al significado. La luz que ilumina el monumento -como recurso estético-, posibilita esta sensación sentida y por sentir de un espacio que entra en tensión por la espacialidad de los cuerpos, por su exposición hacia el sentido de su propio límite, hacia el mundo que se encuentra fuera de la cúpula y que se aleja de ese lugar. Los cuerpos viajan por la luz desde el adentro de las hospederías que exponen la indigencia como partida.

Por esto las obras de Jaar -no solamente la escrita aquí- tocan y tocan en el lugar de su extensión. Como sostiene Nancy, el cuerpo se hace otro al tocarse ahí, al ser tocado ahí en el sentido de la apertura provocada. Por esto el filósofo señala que "de un cuerpo no hay nada que descifrar-salvo esto, que la cifra de un cuerpo es ese mismo cuerpo, no cifrado, extenso (...) Mientras los cuerpos estén ahi, disfrutan de la claridad del alba -ella misma lábil en su evidencia, diversa, pausada,

54 Nancy, Jean -Luc. Corpus. Madrid, España: Arena Libros, p. I3. 
desplazada por toques" ${ }^{55}$. El cuerpo sugerido en el sentido de la luz, es a su vez, el cuerpo de la obra que en su plasticidad, que en su imagen y como ofrecimiento de los cuerpos entre sí, tienen lugar todas las existencias indigentes del mundo.

Sigamos con las interrogaciones: ¿Qué sentido tiene concentrar la obra de Jaar en el cuerpo de la invisibilidad miserable? Precisamente porque ahí radica su sentido, no como significación ni presencia de una determinación denotada, que tendería a presentar sus razones sobre sí misma ${ }^{56}$. El sentido es justamente lo opuesto, su apertura en su propia alteridad, el cual se expone en su distanciamiento, en su ausencia o en su lejanía. Se podría decir que la obra de Jaar en su representación, se ha donado como tal ya que la propia significación se ha puesto en su propio límite, en otras palabras, todos los cuerpos contenidos en la luz del monumento y en el lugar en que cada vez es pulsado el botón que lo ilumina, -desde las hospederías-, se nos ha presentado el límite de la obra propiamente tal en tanto presencia-a-distancia de las ausencias de aquellos cuerpos.

El sentido vendría a ser algo así como la posibilidad de las significaciones que no se han realizado manifiestamente y que quizás sus retornos sean, precisamente, aquellos que se exponen en la luminosidad del edificio. Para Nancy, (...) no se trata de ajustar una mira, sino de dejar que la cosa se presente en verdad (...) Lo que es verdadero no es una conformidad de lo presentable y de su presentación, que guardará siempre lo presentado a distancia de representación, sino el surgimiento

55 Ibíd. pp. 38-39.

56 Es interesante como Nancy (2003) se refiere al proceso de significación ya que "se vacía precisamente porque cierra su proceso subjetivo: no tiene por sentido más que así misma, en su inercia, es decir, a la vez su propio deseo, su propia proyección, su propia distancia de representación, además de su propia representación de la distancia”. El Olvido de la Filosofía. Arena Libros, Madrid, España, p. 48. 
de una presencia ${ }^{57}$ ". Por esto el sentido de la obra nos expone en un lugar común, que junto con ella, entramos en su apertura, entramos en con-tacto como una forma que nos interrumpe... "La interrupción está al borde; o mejor, forma el borde donde los seres se tocan, se exponen, se separan, comunican asi y propagan su comunidad ${ }^{58}$.

En este límite, que a su vez soporta todos los cuerpos, la comunidad recibe la obra aludida, la comunidad recibe el sentido cada vez que esta ausencia se convierte en la posibilidad de referirse a ella. Alfredo Jaar, en su reparto de sentido, desplaza los cuerpos por el espacio y sorprende todas las significaciones para que en su lugar y entonces, se produzcan nuevas razones significadas. Por tanto, "el paso del pensamiento suspendido sobre este sentido ya nos ha tocado (...) Todos los cuerpos, los uno fuera de los otros, hacen el cuerpo inorgánico del sentido (...) Todos los sentidos son el sentido, el sentido del mundo es el mundo del sentido ${ }^{59}$ ".

La cúpula que instala la obra, se transformó en un espacio socialmente doloroso. Cito a Jaar (...) y tendrá así el poder de transformar la condición de las personas sin hogar de Montreal ${ }^{60}$. Esta última cita del texto del artista, remite al lugar donde la obra cobra su propia luz y que sin duda, la Comunidad es iluminada con asombro. Quizás uno de los textos más sentidos que han hablado del tema, ha sido el de Maurice Blanchot "La Comunidad Inconfesable". Señala el filósofo:

57 Ibíd. p. 59.

58 Nancy, Jean-Luc. La Comunidad Inoperante. (2000) Santiago, Chile: Lom Ediciones, p. Io8.

59 Nancy, Jean- Luc (2003). El Sentido del Mundo. Buenos Aires, Argentina: La Marca, pp. 28, I03, 233.

60 Transcribo el texto en francés como aparece en la hospedería: "et aura ainsi le pouvoir de transformer la condition des sans-abri de Montréal». 
Mantenerme presente en la proximidad del prójimo que se aleja definitivamente muriendo, hacerme cargo de la muerte del prójimo como única muerte que me concierne, he ahí lo que me pone fuera de mí y lo que es la única separación que pueda abrirme, en su imposibilidad, a lo Abierto de una comunidad ${ }^{61}$.

El hombre moderno, los hombres todos, los cuerpos en la comunidad, han venido reclamando una pérdida paulatina y creciente sobre la posibilidad de compartir el sentido y el sentir el mundo. Sigamos con Nancy:

Es posible que el hombre no desee, en el fondo, otra cosa que el "mal": no el buen vivir de Aristóteles, que exige un complemento siempre renovado a la "vida", una expansión más allá de la necesidad, sino, por el contrario, ese otro complemento y esa otra expansión que puede llevar a cabo la aniquilación tanto de sí mismo como de los otros, y de lo común así reducido a la común carbonización. Sí, eso es posible, y la era actual de la humanidad nos representa una comunidad de osarios, hambrunas, suicidios y embrutecimientos ${ }^{62}$.

Sin embargo, el mundo y la comunidad de la cual participamos, también claman en silencio por su propio valor como existencia. Si para Nancy nosotros hacemos el sentido, es porque existimos en la medida que la existencia de los otros se transforma en un habitar-nos como seres sociales. Este imperativo nos habla del ser singular/plural que somos. Extraña fórmula de sentido existencial, que el filósofo lo manifiesta

61 Blanchot, Maurice (2003). La Comunidad Inconfesable. Madrid, España: Arena Libros, p. 24.

62 Nancy, Jean-Luc. La Verdad de la Democracia (2009). Buenos Aires, España: Amorrortu, p. 53 . 
como el origen de un particular reparto de las singularidades y que permite el aparecer de la comunidad. Somos seres en común en una permanente ausencia de relaciones, no videntes del otro y ciegos de la propia comunidad a la cual se pertenece. Este hecho manifiesta una condición de transformación en la medida que la ausencia del otro, llega a un límite... márgenes que la obra de Jaar precipitó en su transgresión.

La creación del artista puso en común el propio estar de la obra, su propio aparecer en la ciudad, su propia luminosidad y en consecuencia, su destello propio que nos hizo estar junto con los otros cuerpos de la invisibilidad del dolor. En esta singularidad plural, tocamos la obra porque fuimos tocados por ella: "tocamos en la medida en que nos tocamos, y en que tocamos el resto en cuanto es. Nos tocamos en tanto que existimos. Tocarnos es lo que nos hace nosotros, y no hay otro secreto por descubrir o por esconder tras este tocar mismo, tras el "con" de la co-existencia" 63 . "Lights in the City", no habla en particular, o si se quiere, singularmente de los sin casa de Montreal, por el contrario, se puede suponer en su exclusividad como una presencia que dispone el espaciamiento de todas las singularidades sin hogar del mundo. Cada uno de estos hombres, corresponden a una apertura hacia el mundo, una llegada cada vez a una nueva presencia del mundo. La obra se distancia de su lugar de origen ya que revela un secreto que solamente el sentido más allá de ella puede declarar: su posibilidad de ser obra de arte y co-presencia del mundo en la representación de todos los hombres, que en ausencia o invisibles, se transforman en luces para una ciudad.

\section{La exposición de los cuerpos en las hospederías}

En la pared de las hospederías, los indigentes pueden leer este texto escrito por Alfredo Jaar:

63 Nancy, Jean Luc, Ser Singular Plural. Madrid, España: Arena Libros, p. 29. 


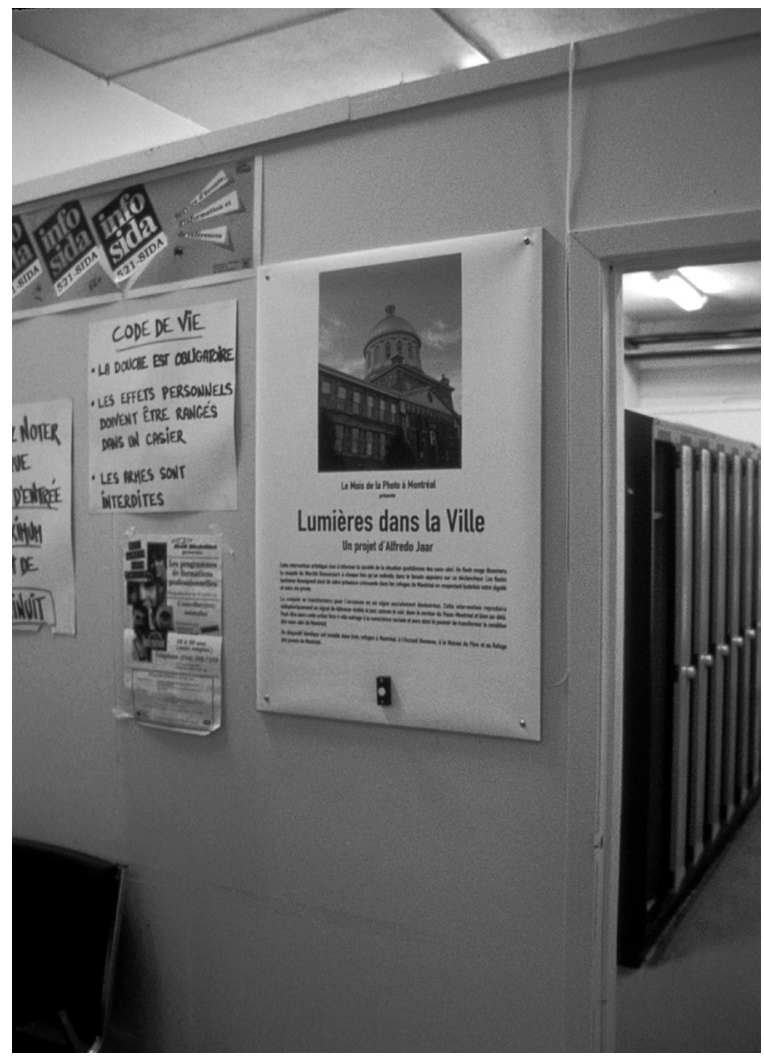

Le Mois de la Photo à Montréal

Lumières dans la Ville

Un projet d`Alfredo Jaar

Cette intervention artistique vise à informer la société de la situation quotidienne des sansabri. Un flash rouge illuminera la coupole du Marché Bonsecour á chaque fois qú un individu dans le besoin appuiera sur ce déclencheur. Les flash lumineux témoignent ainsi de votre 
présence croissante dans les refuges de Montréal en respectant toutefois votre dignité et votre vie privée.

La coupole se transformera pour l'occasion en un signe socialment douloureux. Cette intervention reproducirametaphoriquement un signal de détresse visible le jour comme le soir, dans le secteur du Vieux-Montréal et bien au-delá. Peut-étre alors cette action fera-t-elle outrage á la conscience sociale et aura ainsi le pouvoir de transformer la condition des sansabri de Montréal.

Un dispositif identique est installé dans trois refuges à Montréal : à l'Accueil Bonneau, à la Maison du Père et au Refuge des Jeunes de Montréal ${ }^{64}$.

64 El Mes de la Fotografía en Montreal. Luces en la Ciudad. Un proyecto de Alfredo Jaar. Esta intervención artística tiene por objeto informar a la sociedad de la situación diaria de las personas sin hogar. Un flash rojo iluminará la cúpula del Mercado Bonsecour cada vez que un individuo en la necesidad se apoye sobre este disparador. El flash luminoso da prueba así de su presencia creciente en los refugios de Montreal respetando no obstante su dignidad y su vida privada.

La cúpula se transformará para la ocasión en un signo socialmente doloroso. Esta intervención reproducirá metafóricamente una señal de desamparo visible en el día como en la tarde, en el sector del Viejo-Montreal y bien más allá. Puede ser entonces esta acción una ofensa a la conciencia social y tendrá así el poder de transformar la condición de las personas sin hogar de Montreal.

Un dispositivo idéntico se instala en tres refugios en Montreal: en la Acogida Bonneau, en la Casa del Padre y en el Refugio de los Jóvenes de Montreal. En www.alfredojaar.net 



\section{EPÍLOGO}

Sin lugar a dudas, el cruce entre filosofía contemporánea y la producción artística se ha transformado en nuestros días, en una necesidad primordial para el escritor que trata de realizar la puesta en escritura de lugares desconocidos y a distancia de cualquier significación que pudiese determinar y clausurar su permanente apertura. Esta verdadera traza y trayectoria de un conjunto de supuestos e interpretaciones, fueron tejiendo en este libro un entramado de posibilidades para poder acceder al cuerpo moderno desde el movimiento del tacto de la luz en la obra de Alfredo Jaar y en particular, tomando una de sus obras más emblemáticas: "Lights in the City". La obra como gesto, expresa una con-moción que se constituye como imagen, tanto figurativa como abstracta, reveladora u oculta de intenciones pulsionantes y abiertas a su significación, en un aquí y en un allá simultáneos. El gesto de la instalación le es propio al cuerpo y se hace cuerpo para conducirnos a una acción que presenta un hecho y un estado social moderno.

La fuerza significante de Jaar, posee la cualidad -tanto en su movimiento, como en sus enunciaciones- de constituirse como una serie de opacidades corporales que revelan un conjunto de secretos estéticos en lo que disimula u oculta, cargándose de sentidos de expresión y situados en la movilidad de los cuerpos enviados en la exposición de su silencio. Si asumimos que el gesto, comunica como lenguaje, más allá de la palabra, se puede pensar en una conexión entre el gesto y el movimiento del sentido. Es más, el gesto es movimiento en la medida que lo constituimos como una acción que pone en circulación el espacio, el tiempo y la intensidad. En este sentido la instalación, espacia todos los lugares, todo el tiempo se hace presente y convoca el imaginario de los 
posibles sentidos que le podemos atribuir a la obra. La obra también es un pre-texto en el imaginario que sin duda nos acerca al abismo de los bordes, límites y cercanías de un adentro y un afuera, para que precisamente aparezca el ser-en-el-mundo, ser-en-la instalación como el gesto de un movimiento sensible.

Con lo relatado en este libro, podríamos aventurarnos a enunciar un supuesto reflexivo y sensible, que resignificara la experiencia de la creación artística contemporánea:

La obra "Lights in the City" de Alfredo Jaar, puede suponerse como la exposición de una de pulsión de luz y una especie de luminosidad gesto-sensible que interrumpe la significación evidente del destello proyectado desde el edificio de la instalación. Desde aquel lugar, se fundaría una posibilidad de advenimiento del cuerpo en la luz, del cuerpo/luz como el tacto del sentido. Este sentido es el que puede tocar el sentir del espectador como una nueva forma de interrogar la obra, que evidencia nuevas posibilidades de pensar el significado de ésta y como una especulación que transforma el soporte luminosidad de la creación -recordando la marginalidad en Montreal y del mundo- como el sentido de un aparecer de cuerpos expuestos a nuevas sensibilidades en su representación. Se tensiona entonces, el resplandor visible de la obra, para transitar el cuerpo en su exposición y en su distancia al imaginario convencional.

La obra que sin duda representa el mundo y particularmente los países subdesarrollados como el nuestro, nos instala también desde el ojo observante y vidente un ser que se encuentra situados en el mundo y que mira las sensaciones provocadas por esos cuerpos invisibles y en permanente movimiento. Al contemplar el movimiento de aquellos, los otros, el cuerpo vidente moviliza sus sentidos en torno a su posibilidad de apropiación del sentido. Cuerpo que se escapa en el movimiento de las luces sobre la ciudad de Montreal y en sus sombras. Los cuerpos reflejan como espejos las intensidades que desbordan su propio límite. Estos cuerpos reflejados en sus dobles, recordarían las salas en las 
hospederías donde la imagen del sí mismo marginal, como reflejo de su extra cuerpo, evidencia el tacto de la imposibilidad de significar esa experiencia como abandono a su propio sentir. Deleuze manifiesta en referencia al gesto en movimiento, que dentro del imaginario de las representaciones, la sombra, tiene tanta relevancia como el cuerpo, en tanto que presencia/ausencia de ese acontecimiento, el cuerpo se escapa por su invisibilidad. Pensar los cuerpos desde la brillantez de la imagen luz -formas, figuras, manchas, retratos, contorsiones, espasmos, historias, mundos- en la obra de Jaar, se transformaron en accesos que permitieron narrar la posibilidad de ubicarse en los límites del sentido de la significación de la obra. Lo necesario de su actualidad no sería sino una especie de toque, un tocar justamente aquello que no cierra la posibilidad de pensar el cuerpo como un acto descifrado en la totalidad/partes del sentido de la instalación, sino en el sentido como presentación del sentido de presencia de los cuerpos en una exposición que se revela en la sensación.

Con lo señalado, pensamos también, el aparecer de todos los cuerpos representados en la luz y en esos cuerpos frente al observador, que manifiestan la acción de una serie de fuerzas e intensidades que actúan sobre las partes de la corporalidad como principios de escapatoria, de espaciamiento y exposición. Estas fuerzas, materializadas en los cuerpos de la pobreza, se transformarán siempre en impulsos necesarios, en movimientos de sensaciones capaces de descifrar la exposición de los cuerpos más allá de las tradicionales maneras de presentar la materia, trazos y figuras del artista.

Este libro fue un momento para situarse en el afuera de la obra y volver a mirar todos esos cuerpos de la singularidad/cuerpo que murmuran algo más allá de su representación. Cualquier posibilidad de nuevas significaciones tendrá que revelarse a partir de la propia exposición del sentido del cuerpo, del sentirse tocado por el cuerpo y sus infinitas partes. En otras palabras, dejar que el cuerpo se constituya en el espacio de lo abierto, es decir, donde comienza su presencia y situado 
en el límite de su significado. El cuerpo toca el límite de su sentido, en la medida que el sentido/significado es interrumpido en otro sentido del sentido: en el sentido del sentir, es decir, en el sentido del tacto que los cuerpos de la instalación pueden realizar.

Con la escritura de este libro, logramos esbozar un pequeño momento sobre la instalación. Ningún pensamiento del arte, ni el arte del pensamiento en esta obra, podrían descifrarnos lo que ocurrió y seguirá aconteciendo. ¿Qué es lo que se expone de ese acontecer permanente?, ¿qué es lo que es puesto fuera cuando se vuelve a la obra? La sensación que provoca "Lights in the City" susurran el murmullo de una distancia, de una separación, de una exposición del sentido de sentirse tocados por el sentir de una marginalidad invisible. Los cuerpos enviados al firmamento por la brillantez de la instalación, dejan entre-ver una suerte de resistencia a cualquier circuito de significantes o definiciones de moda sobre el arte. Una murmuración suspendida y supuesta, que niega la imposibilidad de ser cuerpos invisibles al mundo, ya que no existe una invisibilidad o silencio absoluto, precisamente porque el mundo habla también desde su opacidad.

Los cuerpos situados en las hospederías, narraron desde la iluminación de la instalación, una manera de hacer presencias sus ausencias en las ciudades. Por esto, la comunidad de seres en ausencia o en la marginación, reclama el distanciamiento de la exposición y espaciamiento, no como alienación sino como una manera de entrar en contacto y darse sentido los unos con los otros. Si el sistema político y social imperante nos pone en un límite es porque ha llegado a un límite su aceptación. ¿Será que esta instalación nos recuerda permanentemente este límite? Precisamente en los bordes de esta obra, escuchamos su resonancia, su tono, sus vibraciones, sus fugacidades de venida y de retirada: un silencio propio de su habla cuando la creación nos deja al borde de la palabra y nos vuelve al cuerpo. Los cuerpos expuestos ahí y los que se seguirán exponiendo en las obras de Jaar, nos hacen sentir intensidades comprometedoras y deseantes. Cuando el cuerpo se siente a sí mismo 
desde el exterior, hay un cuerpo que toca su interior. Hay un cuerpo que nos toca a todos. Puede ser que este toque de los cuerpos visibles o invisibles de las obras de Jaar, recuerden la resonancia y murmuración del silencio de todos los cuerpos donados en los soportes artísticos.

La locura del propio cuerpo permite interpretativamente pensar que las imágenes que logran proyectarse desde la cúpula intervenida por Jaar, representan esta suerte de sonoridad de sentidos, del afuera y del adentro, que tratan de revelar y exponer esos cuerpos marginales en la tracción, contracción y atracción que manifiestan. De un movimiento a otro hay resonancia entre múltiples resonancias. Lo que se nombra entonces, con el cuerpo en la obra, no es sino esa acústica del testimonio entre nuestros espacios de emoción. Esta puntualidad (el sentido de la invisibilidad de la brillantez de la imagen de los cuerpos) que marca el límite entre lo interno y lo externo -punto inestable de equilibrio- estaría dado por la interrupción que el sentido despliega hacia un adentro del propio cuerpo, como una estancia de lugares comunes entre un aquí y un allá, una suerte de movimiento permanente.

La imagen de Jaar y las creadas en nuestro propio imaginario, que sin duda presentan citas del sentido -referencias al mundo y a los mundos posibles que las obras convocan- instalan al ojo observante y vidente, la alegoría de movimientos que pausan los sentidos en torno a la posibilidad de entrar y salir de ellas. Cuerpos que se escapan en los movimientos y en sus silencios. Cuerpos dobles, reflejados en ese símil espejo, cobran la potencia de extraer desde su física el despliegue de su existencia. Es esta extraña manera de co-pertenencias lo que posibilita el logro de estar en la unidad de nuestro cuerpo en conjunto con la imagen y las imágenes artísticas, y es a partir de éstas que nuestra visión, nuestro tocar y todos nuestros órganos de los sentidos se nos aparecen y se nos revelan.

En la instalación "Lights in the City", este ir y venir de la locomoción corporal, se expresa con los cuerpos que cifran simultáneamente, ser presente, pasado y devenir. Para Deleuze el pasado no sucede al 
presente que él ya no es, coexiste con el presente que él ha sido. El presente es la imagen actual, y su pasado contemporáneo es la imagen virtual, la imagen en espejo. Por esto, movimiento y tiempo nos tocan en la medida en que fundamos la relación co-participante del sentido de apropiación del mundo, de las imágenes, de las obras. Claro está que los cuerpos presentados bajo dichas condiciones artísticas o bajo cualquier soporte para el arte están presentes y en presencia. Esta verdadera poética del cuerpo tiene su razón de ser en un lugar: en la conjunción del espacio, las luces, las materias, los sonidos, los chirridos, el movimiento, las intensidades, los fluidos, la transpiración de las hospederías y la experiencia de sentirse sentir tocado por el arte...

Sin palabras, sin significación, solamente en la descarga de escuchar el silencio del otro en la cúpula del "Mercado Bonsecour" y de todos los que padecen la miseria del mundo. 


\section{BIBLIOGRAFÍA}

Alfredo JaAr (2006), Conversaciones en Chile, 2005. Barcelona, España. En Catálogo JAAR SCL.: Actar.

ARISTóteles. Acerca del Alma, Libro II (I978). Traducción Tomás Calvo. Madrid, España: Gredos.

Baвна, Homi. Luciérnagas Atrapadas en Melaza. Temas de Traducción Cultural. Texto sugerido en el curso «Escrituras Sobre Arte», impartido por Adriana Valdés, Doctorado en Filosofía, mención Estética, 2007.

Blanchot, Maurice (2003). La Comunidad Inconfesable. Madrid, España: Arena Libros

Cioran, Emil (i 986). La Caída en el Tiempo. España, Barcelona: Planeta-Agostini. Traducción de Esther Seligson. En http://estafeta-gabrielpulecio.blogspot.com/2010/03/emil-m-cioran-retrato-delhombre.html

Deleuze, Gilles, Guattari, Félix (2005). El Antiedipo. Capitalismo y Esquizofrenia. Buenos Aires, Argentina: Paidós.

(2006). Mil Mesetas. Capitalismo y Esquizofrenia. España:

Pre-Textos.

Deleuze, Gilles (2003). Lógica de la Sensación. Madrid, España: Arena.

Derrida, Jacques (1989). La Escritura y la Diferencia. Barcelona, España: Editorial Antrophos. 
Didi-Huberman (2008). La Emoción no dice "Yo". Diez Fragmentos Sobre Libertad Estética. En Alfredo Jaar. La Política de las Imágenes. Adriana Valdés, Editora General, Metales Pesados, Santiago, Chile.

Foucault, Michel (i992). Microfísica del Poder. Madrid, España: La Piqueta.

(2005). Las Palabras y las Cosas. Argentina: Siglo XXI.

Husserl, Edmund (1994). Problemas Fundamentales de la Fenomenología. Madrid, España: Alianza.

Maharaj, Sarat. Xenoepistemias: Instrumental Hechizo (Provisorio) para Sondear (Tantear) el Arte Visual como Producción de Conocimiento y los Regimenes Retinianos. Texto sugerido en el curso «Escrituras Sobre Arte», impartido por Adriana Valdés, Doctorado en Filosofía, mención Estética, 2007.

Marchant, Patricio, "Discurso contra los Ingleses”, en Revista de Crítica Cultural, $\mathrm{Nro}^{\circ}$ 2, noviembre de I99 I, Santiago, Chile.

Merleau-Ponty, Maurice (I970). Lo Visible y lo Invisible. Barcelona, España: Seix Barral.

(1997). “Fenomenología de la Percepción”, Serie. Colección Historia, Ciencia, Sociedad. Barcelona, España: Península.

NANCY, JEAN LUC (2000). La Comunidad Inoperante. Santiago, Chile: Lom Ediciones

(2003). Corpus. Madrid, España: Arena Libros S. I.

(2003). El Olvido de la Filosofía. Madrid, España: Arena Libros. (2003). El Sentido del Mundo. Buenos Aires, Argentina: La Marca. (2006). Ser Singular Plural. Madrid, España: Arena Libros. 
(2008). Las Musas. Buenos Aires, Argentina: Amorrortu.

Oyarzún, Pablo (2003). El Rabo del Ojo. Prólogo Para Una Muestra de Arte SiteSpecific. Santiago, Chile: Arcis.

Oyarzún, Pablo, Richard, Nelly, Zaldivar, Claudia (editores). Arte y Politica. Santiago, Chile: Universidad Arcis.

Patocka, Jan (2005). Introducción a la Fenomenología.

España: Herder.

Ranciere, Jacques (2008). El Teatro de las Imágenes. En Alfredo Jaar. La Política de las Imágenes. Adriana Valdés, Editora General. Santiago, Chile: Metales Pesados.

Richard, Nelly. Lo Politico en el Arte: Arte, Politica e Instituciones. En www.hemisphericinstitute.org

Rovatti, Pier Aldo. La Locura del Propio Cuerpo. En Cartografías del Cuerpo (2004). España: CENDE.

Valdés, Adriana (2006). Apuntes para una Poética de Alfredo Jaar. En Catálogo “JAAR SLC 2006”. Barcelona, España: ACTAR.

ZÚÑiga, Rodrigo (2006). El Sitio y la Fórmula. En Catálogo JAAR SLC. Barcelona, España: ACTAR.

(2008). La Demarcación de los Cuerpos. Santiago, Chile:

Metales Pesados. 
Jorge Ferrada Sullivan

Fuente fotográfica de las imágenes

1.- Fuente Fotografía Lights In The City.

Descripción: Obra del artista Alfredo Jaar "Lights in the City", Montreal, 1999.

2.- Fuente Fotografía Textos Hospedería

Descripción: Texto escrito en las hospederías referida a la obra "Ligths in the City”, de Alfredo Jaar. Montreal, 1999. 


\section{ANEXO \\ ESCRITURAS TEXTUALES EN LAS OBRAS DE ALFREDO JAAR}

Se presentan a continuación, una serie de citas de autores que han escrito a propósito y con Jaar, ya sea revelándolo en sus relatos, como en conversaciones y encuentros en su nombre.

Para el artista, la utilización de la luz implica en sus obras:

Hago las intervenciones públicas porque necesito salir del cubo blanco perfecto, del mundo del arte, que para mí es bastante ficticio. Las intervenciones públicas ocurren en el mundo real, y me mantienen real.

Alfredo Jaar (2006), Conversaciones en Chile, 2005. En

Catálogo "JAAR SCL. Actar, Barcelona, España, p. 74.

Siempre hay un elemento de luz: lo necesito. Es verdad que está enmarcada en un espacio muy oscuro. Siempre me pregunto cuánta luz quiero dejar ver: es un elemento clave del programa. Es una cosa objetiva, un elemento de esperanza. En cada obra está. En algunas no es tan evidente, pero está. Gracias a esta luz puedo seguir haciéndolas.

Alfredo Jaar (2006), Conversaciones en Chile, 2005. En Catálogo JAAR SCL. Barcelona, España: Actar, p. 87.

Mediante performances o instalaciones que combinan una coreografía arquitectónica y una durée cinematográfica, explora 
lo que pueden hacernos las imágenes, de modo de enfrentarnos tanto a la visibilidad como a la invisibilidad en calidad de signos de cómo conocemos o dejamos de conocer el sufrimiento -la vida y la muerte- de los demás.

Pollock, Griselda (2008). Sin Olvidar África. En Alfredo Jaar. La Política de las Imágenes. Adriana Valdés, Editora General. Santiago, Chile: Metales Pesados, p. 93.

Lo poético, en la obra de Jaar, es lo que aspira a hacer que esa visibilización tiemble en el borde mismo de su posibilidad, y "así irradie", se vuelva "radiante". Es lo que, más allá de dar información puesta en palabras, crea experiencias visuales que sugieren y hasta refuerzan a "desenmarcarse", a exigir los hábitos mentales del pensamiento moderno (...) a entrar en una extrañeza y en una deriva, y finalmente, a conmoverse...

Valdés, Adriana (2006). Apuntes para una Poética de Alfredo Jaar. En Catálogo "JAAR SLC 2006”. Barcelona, España: Actar, p. 6.

(...) en incontables ocasiones la luz se ha vuelto cuerpo, letra: escritura. Una luz que se blinda a veces con la armadura del neón, por ejemplo, y que encintada de este o de algún otro modo se deposita sobre muros, sobre agua, sobre edificaciones públicas, sobre iglesias. Inscrita en estas superficies, traza sobre ellas nombres de ciudades, de personas, citas de poemas (...) como si la mención del nombre alumbrara una presencia, o trajera a la luz al ausente, a la sombra murmurante de ese nombre.

Zúñiga, Rodrigo (2006). El Sitio y la Fórmula. En Catálogo JAAR SLC. Barcelona, España: Actar, p. 117.

(...) en rigor se trata de una vida que puede no ser visible, que puede no dejar huella, que incluso puede no tener seña; es decir, que porta en sí misma su desaparición como forma extrema de 
la proscripción. Y es esa potencia de infinito desvanecimiento lo que, en buena medida, se hace aparecer en el escenario de la ciudad de Montreal.

Zúñiga, Rodrigo (2008). La Demarcación de los Cuerpos., Santiago, Chile: Metales Pesados, p. 109.

Hacer luz: abrir una grieta, precipitar una crisis, dar a pensar. Hacer luz, en este caso, en el mecanismo petrificado de la significación, de la representación cultural que se detenta y se naturaliza. Hacer luz para “comunidades carentes de imágenes” ...

Zúñiga, Rodrigo (2006). El Sitio y la Fórmula. En Catálogo JAAR SLC. Barcelona, España: Actar, p. 119.

El recuento político de aquello que vale tomar en cuenta es también la operación poética que pone una palabra o una imagen por otra, una parte por el todo, una multiplicidad por la otra. Esa identidad entre la redistribución política de lo que se toma en cuenta, por una parte, y el uso poético de las figuras, por otra, es el fundamento de muchas de las instalaciones de Alfredo Jaar.

Rancière, Jacques (2008). El Teatro de las Imágenes. En Alfredo Jaar. La Política de las Imágenes. Adriana Valdés, Editora General, Santiago, Chile: Metales Pesados, p. 78.

El ejemplo de Jaar atestigua, precisamente, la intransable urgencia de esta pesquisa permanente: basta con referir el descalce que su trabajo opera respecto de la tradición documental, al insertar las preocupaciones socio-políticas en el contexto del desgaste de la conmoción afectiva de las imágenes.

Zúñiga, Rodrigo. O(ot)o(b)e(r)-OBSoLeTe. Texto sugerido en el curso «Escrituras Sobre Arte», impartido por Adriana Valdés, Doctorado en Filosofía, mención Estética (UCHILE), 2007. 
Ni simple ornamentación ni simple placer, la belleza lacónica y generalmente minimalista de los trabajos de Jaar se llama para él "lo poético", y es una dimensión más del pensamiento, precisamente la que "la obra expresa de un modo no verbal", su diferencia específica en relación con la información”.

Valdés, Adriana (2006). Apuntes para una Poética de Alfredo Jaar. En Catálogo "JAAR SLC 2005”. Barcelona, España: Actar, p. 53.

El tipo de obra que expone Jaar, se encuentra inserta en el mundo para tener presente y recordarnos en la memoria que somos parte de la realidad y no ajenos a ella. Podemos escribir y reescribir críticamente la situación actual del mundo, sin embargo el poder de las imágenes y sobre todo cuando éstas creativamente producen el tipo de obra al estilo de Jaar, provocan que la visualidad se exponga en el límite de la conmoción, de la emoción, del pensamiento y de la acción.

Ferrada, Jorge (2008). Coloquio El Cuerpo como Arquitectura del Sentido. Santiago, Chile. Universidad de

Chile.

La obra completa (Estudios sobre la Felicidad, I980 - I98I) corresponde a una serie de ocho fotografías en blanco y negro, cinco apaisadas y tres verticales, que registran intervenciones realizadas en la ciudad de Santiago y sus alrededores, incorporando la pregunta “¿Es Usted Feliz?” al paisaje, en vallas publicitarias de pequeño y gran formato, con tipografía negra sobre fondo blanco. Las imágenes exhiben en su impresión, un marco correspondiente a una película fotográfica, la cual nos indica su condición de registro, evidenciando el medio utilizado para documentar la ejecución de la obra y su carácter efímero. http://www.mac.uchile.cl/educacion/colección_arte_experimental/alfredo_jaar.pdf 

Este libro ha sido posible gracias al trabajo de:

Autoridades universidad de los lagos

Óscar Garrido Álvarez, Rector Universidad de Los Lagos Patrick Puigmal,

Vicerrector de Investigación y Postgrado SANDRA Ríos NúÑEz, Directora de Investigación

\section{Consejo Editorial}

Gonzalo Delamaza Escobar, Doctor en Sociología Diana Kiss de Alejandro, Magíster en Comunicación Patrick Puigmal, Doctor en Historia Nicole Fritz Silva, Doctora (C) Internacional en Actividad Física y Salud Jaime Rau Acuña, Doctor en Ciencias Biológicas Gonzalo Miranda Hiriart, Doctor en Salud Pública Mita Valvassori, Doctora en Literaturas Comparadas Andrea Minte Müzenmayer, Doctora en Educación Ricardo Casas Tejeda, Doctor $(\mathcal{C}$ en Ciencias Humanas 


\section{Comité Editorial Especializado Arquitectura y Artes Visuales}

Jorge Ferrada Sullivan, Doctor en Filosofía

Mario Del Castillo Oyarzún,

Doctor en Periferias, Sostenibilidad y Vitalidad Urbana

Claudia Castillo Haeger,

Doctora en Periferias, Sostenibilidad y Vitalidad Urbana

Catalina Montenegro González, Doctora en Artes y Educación

Ignacio Soto Silva, Doctor (C) en Musicología

\section{Comité Editorial}

Ricardo Casas Tejeda, Director

Carolina Carillanca Carillanca,

Coordinadora editorial de libros

Gabriela Balbontín Steffen, Editora

Kiyen Clavería Aguas, Ilustradora

Alexis Hernández Escobar, Director de arte

\section{Área de Administración}

Daisy Ovando Millan, Secretaria Vicerrectoría de Investigación y Postgrado

Cecilia Cárdenas Garcés, Profesional de Apoyo de la Dirección de Investigación

Cristina Navarro García, Jefa Unidad Logística, Adquisiciones y Bodega

Alejandro Jiménez Alvarado, Encargado de página web 
Relatos sobre arte contemporáneo.

Estéticas de la presencia en la obra de Alfredo Jaar

(C) Jorge Ferrada Sullivan

En su diseño se utilizaron las tipografías Fontín 12 y Sabon LT Std 8, 10, 11 y 12

Las imágenes fueron autorizadas por Alfredo Jaar y compartidas por el artista para su utilización en este libro.

Sus interiores han sido impresos sobre papel bond ahuesado de 80 gramos y para la portada papel couché opaco de 350 gramos más laminado opaco en tiro.

Ejemplar cocido y encuadernado hotmelt en Salesianos impresores.

El tiraje de esta primera edición es de 1.000 ejemplares.

Impreso el 2021.

Santiago de Chile.

RPI: 2020-A-4293 / ISBN: 978-956-6043-13-3

Desde el Sur

cultivamos saberes, cosechamos libros

www.editorial.ulagos.cl

editorial@ulagos.cl

Cochrane 1070, Osorno 

